\title{
CONSELHOS E REGIMES DE NORMATIZAÇÃO padróes decisórios em municípios de grande porte
}

\author{
Adrian Gurza Lavalle ${ }_{(1,2,3)}$ (iD
}

E-mail: layda@usp.br

\section{Hellen Guicheney ${ }_{(2,3)}$ (D)}

E-mail: hguicheney@gmail.com

\section{Bruno Grisotto Vello}

E-mail: bruno.vello@imaflora.org

(1) Departamento de Ciência Política da USP, São Paulo - SP, Brasil.

(2) CEM (Centro de Estudos da Metrópole), São Paulo - SP, Brasil.

(3) CEBRAP (Centro Brasileiro de Análise e Planejamento), São Paulo - SP, Brasil.

(4) IMAFLORA (Instituto de Manejo e Certificação Florestal e Agrícola), Piracicaba - SP, Brasil.

DOI: $10.1590 / 3610610 / 2021$

\section{Introdução}

Ao longo das últimas três décadas, os conselhos gestores de políticas públicas (doravante, conselhos) encarnaram institucionalmente aquilo que, na Constituição de 1988, eram disposições abstratas, introduzindo o princípio da participação em determinados setores de política (também chamada gestão pública participativa). Por sua vez, a literatura sedimentou um campo de pesquisa próprio e adensou o conhecimento disponível mediante, principalmente, estudos de caso. A envergadura atingida pela institucionalização dos conselhos e o acúmulo de conhecimento de casos suscitaram, então, duas indagaçôes logicamente conectadas: como generalizar o conhecimento sobre os conselhos; e quais são, de fato, os efeitos dessas instâncias de inovação sobre a

Artigo recebido em: 31/Mar/2020

Aprovado em: 31/Jul/2020 operação e o desempenho das políticas? A articulação dessas duas interrogaçóes encontrou, inicialmente, expressão clara na agenda da autodenominada "efetividade das instituiçôes participativas", a qual visava, sobretudo, compreender o efeito agregado dessas instâncias sobre o desempenho de políticas (Avritzer, 2010; Pires, 2011). Tal agenda estimulou o diálogo entre o campo de estudos da participação e a literatura de políticas públicas, iniciado vagarosamente ao longo da consolidação institucional dos próprios conselhos. Nesse diálogo, frutificou o conhecimento mais consolidado, ainda hoje, sobre os conselhos.

Grosso modo, é possível afirmar que os diagnósticos sobre a atuação dos conselhos, com o tempo, estabilizaram-se na literatura e se tornaram passíveis de certa generalização porque identificaram um conjunto de características estáveis associadas a diferentes setores de políticas sociais. Assim, a índole setorial de determinados conselhos, delineada a partir do plano federal, traria consigo uma comunidade 
de políticas - com seus correspondentes atores civis, privados e públicos -, a existência ou não de fundos, a disposição ou não de mecanismos para forçar a observância de suas resoluçóes etc. Em outras palavras, regimes nacionais de regulação setorial são, em grande medida, responsáveis pela convergência de características entre conselhos municipais do mesmo setor. Por sua vez, fontes de variação quanto à atuação dos conselhos responderiam preponderantemente a fatores extra-setoriais, ora porque o porte ou as características socioeconômicas e demográficas dos municípios afetam transversalmente as capacidades setoriais da administração local, ora porque a ausência de constrangimentos e de mecanismos de indução federal acentuaria o peso de comportamentos divergentes entre conselhos de distintos municípios.

Argumentamos, no presente artigo, que regimes de normatização subnacional, notadamente os de caráter estadual, podem modificar consideravelmente a atuação dos conselhos. Não obstante a importância da regulação nacional, certas variantes nos estados como a trajetória da política, o escopo de demandas sociais e a saliência de questóes associadas a certas áreas - podem estimular a proatividade dos governos estaduais no que se refere à determinação das atribuiçóes e dos padróes de expansão territorial dos conselhos municipais. Isto, a depender do grau de discricionariedade deixado aos níveis subnacionais pelos mecanismos de indução e coordenação federais. Em tese, então, a distribuição espacial e de atribuiçôes dos conselhos se torna passível de definição pelas normas federais; pela combinação complementar ou concorrente de normas federais, estaduais e municipais; ou mesmo, pela dominância de normas estaduais, a depender da área de política em foco. Assim, interessam de modo particular a este texto as divergências na atuação dos conselhos, eventualmente derivadas de atribuiçóes definidas pela normatização estadual, pois esta pode fazer convergir centenas de conselhos municipais, configurando regimes subnacionais ainda pouco estudados. De fato, regimes estaduais de normatização ainda não mereceram a devida atenção dos estudos focados no funcionamento e impacto das instituiçóes partícipes da provisão de políticas públicas ao nível subnacional, em especial, no que se refere aos conselhos gestores. Por certo, existe também variação na atuação dos conselhos que responde estritamente à política municipal - já identificada alhures (Gurza Lavalle et al., 2016) -, mas, que sendo de natureza mais contingente e, por vezes, excepcional e de difícil tratamento sob a ideia de regimes, não constitui o foco de interesse deste artigo.

Demonstrar a existência e os efeitos de regimes de normatização estadual para a atuação dos conselhos municipais dista, todavia, de ser operação trivial. Aqui, reunimos evidências sistemáticas que apontam para tal existência de modo conjectural, ou seja, mostramos a pertinência empírica e a relevância analítica dessa conjectura. Para realizar tal propósito, o artigo assume um escopo restrito e propóe inovaçóes nos planos analítico e metodológico. No que diz respeito ao escopo, o artigo é descritivo e se propóe a: i) determinar padróes esperados de atuação dos conselhos - aqui aferidos pela sua atividade decisória; ii) estabelecer factualmente a existência de variação significativa intra-setorial, inesperada nessa atuação; iii) mostrar a plausibilidade de atribuir tal variaçáo, de modo conjectural, ao efeito de regimes de regulação estaduais.

Quanto ao plano analítico, e com base em resultados de pesquisa explorados alhures (Gurza Lavalle e Barone, 2015; Gurza Lavalle et al., 2016; Guicheney, 2019), realizamos uma análise comparativa da atuação de conselhos em municípios de grande porte, focando em sua atividade decisória. Encontramos tanto padrôes esperados, quanto inesperados: os primeiros respondem ao diagnóstico setorial da literatura, enquanto os segundos remetem, conforme argumentamos, à presença de regimes estaduais de normatização. Mostramos, a esse respeito, evidências que suportam a plausibilidade de tal conjectura. A distinção entre padróes esperados e não esperados depende da conceituaçáo de tipos de conselhos e da agregação de suas decisóes informada por tal classificação. Em relação à conceituação, aprimoramos uma tipologia de conselhos alicerçada em duas dimensōes: indução, no momento da expansão; e especificação institucional, no momento da operação - sendo que ambas guardam afinidade com mecanismos específicos de normatização. Em relação à agregação de decisóes, empregamos uma tipologia de resoluçóes, testada e estabilizada mediante a classificação de milhares de decisóes tomadas por 
conselhos oriundos de mais de trinta áreas diferentes de políticas. Acreditamos que ambas as tipologias nos permitem examinar e caracterizar - com grau razoável de generalização, para municípios de porte aproximado - relaçóes consistentes entre tipos de conselhos e padrōes decisórios.

Quanto ao plano metodológico, a pesquisa realizou censos dos conselhos e de sua produção decisória, ao longo de sete anos (2005-2011), em cinco municípios de grande porte (escolhidos a partir de uma amostra intencional, segundo disponibilidade de dados): Fortaleza (CE), Belo Horizonte (MG), Porto Alegre (RS), Goiânia (GO) e Guarulhos (SP). A unidade de análise, resolução (também nomeada decisão ou ato administrativo), ${ }^{1}$ bem como a informação sobre a existência de conselhos, foram retiradas dos Diários Oficiais (DOs) dos respectivos municípios, mediante idêntico e minucioso processo de coleta. $\mathrm{O}$ artigo apresenta resultados inéditos, ao comparar a produção decisória de 138 conselhos, em cinco municípios, por meio do exame de cerca de 15 mil resoluçóes pormenorizadamente classificadas. ${ }^{2}$ Com base nesta amostra de municípios, não é, por certo, possível falar em comportamento médio dos conselhos municipais no Brasil; não obstante, o banco de dados utilizado fornece, segundo o melhor de nosso conhecimento, a aproximação mais precisa e abrangente, já elaborada até o momento, sobre as resoluçóes produzidas por tais instituiçôes.

Os resultados evidenciam os ganhos cognitivos das escolhas aqui adotadas. Primeiro, mostram que a generalizaçấo setorial sobre a estabilização dos conselhos, sobre suas rotinas institucionais e seus padróes decisórios é correta, mas requer revisão e modificaçôes restritivas. Segundo, confirmam que quando a expansão territorial e a especificação institucional são animadas principalmente por mecanismos de indução, coordenação e regulação setorial federais, diferenciam-se três tipos de conselhos com seus respectivos padróes de atividade decisória. Terceiro, e mais importante, revelam um padrão inesperado ou "anômalo" que, no melhor dos casos, tem permanecido subexplorado pela literatura, pois, como procuramos mostrar e as evidências sugerem, ele é produto de regimes de normatizaçáo setorial de nível estadual - regimes estes, capazes de estimular a difusão de conselhos em nível municipal, conferir-lhes especificação institucional e, ainda, inseri-los no processo de operação regular da política.

O artigo está estruturado em cinco seçôes, incluindo a presente Introduçáo. Na seçáo seguinte, abordam-se a literatura e o embasamento conceitual e empírico que permitem definir a variaçấo esperada na atuaçáo dos conselhos. A terceira seção justifica brevemente as escolhas da amostra e a unidade de análise; expõe, de modo sucinto, a tipologia de decisóes, além de apresentar os resultados da análise descritiva sobre os padrōes decisórios. Na quarta seção, são levantadas evidências da presença de regimes subnacionais em setores e estados identificados na análise. Por fim, sumarizamos os resultados apresentados e atentamos para suas implicaçōes.

\section{Induçáo, especificaçáo institucional e os resultados esperados}

A literatura sobre conselhos mudou ao longo dos últimos trinta anos (Almeida et al., 2015), em boa medida, seguindo a transformaçáo do próprio objeto. A progressiva consolidação dessas instituiçóes levou naturalmente uma literatura oriunda do estudo dos atores sociais, da ação coletiva e da experimentação institucional participativa a entabular diálogo com o campo de conhecimento das políticas públicas. Afinal, o papel dos conselhos apenas ganharia inteligibilidade à luz de sua posição e funçôes na respectiva política setorial (Tatagiba, 2004). O exemplo mais notável desse diálogo é a agenda da efetividade das instituiçóes participativas (IPs), preocupada com a produção de diagnósticos mais abrangentes sobre os efeitos dos conselhos no desempenho das políticas nos municípios (ver, por exemplo, os números organizados por Pires (2011) e Avritzer (2010)). No diálogo com a literatura de políticas, alguns trabalhos mostram que a presença dessas instituiçóes covaria positivamente com o desempenho de determinadas políticas (Pires e Vaz, 2010; Donaghy, 2011; Boulding e Wampler, 2010), e que a atuaçáo das mesmas dependeria do setor em que se encontram inscritas (Côrtes, 2002a; 2002b, 2015). A definição dos padróes esperados de atuaçáo dos conselhos descansa no conhecimento acumulado graças a essa evoluçáo da literatura. 
Argumentamos que duas dimensóes permitem incorporar tanto o diagnóstico da literatura a respeito da relevância da inscrição dos conselhos em um determinado setor de política quanto ordenar a análise comparativa de sua atividade decisória - aqui considerada como evidência do perfil de atuação. São elas: indução quanto à expansão territorial; e especificação institucional quanto à caracterização de sua potencial inserção no funcionamento regular da política. Com base nessas dimensões, será possível atentar para as características convergentes na presença e atuação dos conselhos, de índole setorial, que decorrem de estímulos e constrangimentos definidos no plano federal; bem como estabelecer uma tipologia abrangente, que permita classificar essas instituições e prever padrões médios na produção de decisôes. É tendo como pano de fundo a convergência setorial que, subsequentemente, serão examinados os fatores que introduzem divergência nos padróes de atuação esperados dos conselhos.

Convém tratar, primeiro, da dimensão da indução, mostrando que a força e coerência de seus mecanismos para a expansão territorial produzem universalização. A expansão dos conselhos, no plano local, apresenta padrão convergente e encontra-se claramente associada a mecanismos federais de indução, principalmente o condicionamento do acesso municipal a recursos da Uniāo, em algumas áreas (Gurza Lavalle e Barone, 2015; Guicheney, 2019; IPEA, 2010; Arretche et al., 2012). A importância desta primeira dimensão parece óbvia, haja vista que conselhos apenas podem atuar - sejam quais forem as eventuais consequências de suas ações - aonde forem criados.

Considerando dados da Pesquisa de Informaçôes Básicas Municipais (Munic), existiam, em 2014, mais de 62.000 conselhos no país, inscritos em 25 áreas e subáreas de políticas. Porém, apenas em um número muito reduzido de áreas os conselhos atingiram patamares próximos à universalização, quando considerada sua capilaridade territorial: apenas os de Saúde, Assistência Social, Alimentação Escolar, Fundeb/Fundef e Direitos da Criança e do Adolescente acusaram presença em mais de 90\% dos municípios do país; sendo que, no caso de Educação, esse percentual é de 87,5\% (IBGE, 2014a). A expansão desses conselhos foi vertiginosa, ou melhor, aos saltos. Veja-se o caso emblemático da Assistência: em um único ano, a Lei Orgânica da Assistência Social (Brasil, 1993) fez crescer a modesta presença de conselhos, de menos de $5 \%$ para mais de $60 \%$, na totalidade dos municípios do país (Ferrari, 2016). Nesse caso, a indução federal foi responsável por tamanha expansão ao condicionar o repasse de recursos a organizações da sociedade civil, executoras da política em nível municipal, ao seu registro no conselho. ${ }^{3}$ Mecanismos de indução federal assim fortes subjazem à universalização do grupo de conselhos inscritos em setores e áreas de política social.

Um segundo grupo - que compreende conselhos como os de Habitação, Meio Ambiente, Cultura, Idoso, Transporte Escolar e Segurança Alimentar está presente entre 20\% e 70\% dos municípios, e sua expansão irregular decorre da definição inconsistente e/ou modesta dos mecanismos de indução federal. O salto na expansão dos Conselhos de Habitação, por exemplo, ocorre a partir de 2005 (Gurza Lavalle e Barone, 2015), precisamente após a criação do Sistema Nacional de Habitação de Interesse Social (SNHIS) e de seu correspondente fundo (FNHIS), cujos recursos restaram acessíveis aos municípios como repasses condicionados pela Lei $\mathrm{n}^{\circ} 11.124$ (Brasil, 2005) à implantação dos conselhos do setor (Maricato, 2006; Arretche et al., 2007). Rodrigues (2017), no entanto, mostra que a própria lei que induziu a expansão dos conselhos, impulsionando sua presença em aproximadamente $60 \%$ dos municípios, solapou sua observância ao autorizar o conselho gestor do fundo de habitação a dispensar a implantação dos conselhos municipais, em função de características territoriais, econômicas, sociais e/ou demográficas locais. Assim, a expansão deste segundo grupo é suficientemente ampla para decorrer da iniciativa descoordenada dos governos municipais, mas os mecanismos de indução federal foram incapazes de estimular a universalização.

Por fim, o grupo mais diversificado de conselhos acusa presença exígua no território, cobrindo de $1 \%$ até $20 \%$ dos municípios, aproximadamente, dependendo da área de políticas considerada. É o caso dos conselhos de Direitos Humanos, Esporte, Juventude, Patrimônio, Direitos da Pessoa com Deficiência, LGBT, Direitos da Mulher, Saneamento, 
Segurança Pública, dentre outros. Nesse caso, como os mecanismos de indução setorial são fracos ou inexistentes, os conselhos tendem a ser implantados ao sabor da política local e a mostrar, portanto, acentuada heterogeneidade.

A composição dos três grupos evidencia a relevância da variável setorial: no primeiro, foram enumerados cinco conselhos inscritos em sistemas de políticas (dentre 6), enquanto no terceiro grupo, predominam aqueles não setoriais ou de áreas transversais. De fato, ao longo dos anos 2000, firmaram-se, na literatura, diagnósticos de que os conselhos apenas podiam ser cabalmente entendidos se estudados à luz de sua inserção em determinado setor, seja mediante a descriçấo de suas atribuiçôes regimentais ou desenho institucional (Tatagiba, 2004; Valença et al., 2002), seja aliando características do desenho institucional à análise das comunidades de políticas setoriais (e.g. Côrtes 2002b; 2002a). Com o tempo, tornou-se claro que o desafio consistia em diagnosticar o lugar ocupado por essas instituiçóes no interior do processo de produção de políticas setoriais (e.g. Tatagiba, 2007b; 2007a), bem como a sua capacidade de incidência nos diferentes níveis federativos (e.g. Côrtes et al., 2009). O diagnóstico de convergência setorial entre conselhos municipais é amplo e inclui não apenas informaçôes sobre suas atribuições e atuação, mas também sobre as comunidades de políticas - inclusive movimentos sociais e organizaçôes da sociedade civil -, os tipos de gestores públicos envolvidos, além de uma compreensão específica sobre o papel da participação na provisão de políticas.

A segunda dimensão, por sua vez, reconduz parte significativa das proposiçóes da literatura sobre o caráter setorial das funçōes e capacidades dos conselhos para sua especificca̧ão institucional. A sobreposição entre o nível de expansão de um dado conselho (derivada de mecanismos de indução federal) e sua inserção funcional, no setor de política específico, é apenas parcial; não fosse assim, bastaria conhecer a trajetória de expansão para derivar capacidades de atuaçãoo. ${ }^{4}$ Em outras palavras, os mecanismos que levam à disseminação dos conselhos não são necessariamente os mesmos que os estabilizam e os tornam operantes na respectiva política. Em tese, mesmo aqueles cuja criação seja determinada por forte indução federal poderiam ser instituídos apenas no plano formal e sequer entrar em funcionamento. Isso ocorre porque é a sua especificação institucional que define quais atividades eles desempenharão e, mais importante, em que processos da produção de políticas eles seráo requeridos.

Entende-se que a especificação institucional insere os conselhos no funcionamento regular da política e, também, constitui uma condição necessária para sua capacidade de operação e, mesmo, para sua estabilização. Ela consiste em disposiçōes normativas do correspondente setor, que condicionam os processos administrativos de definição, implantação, gestão e prestação de contas da política à realização de determinadas funçôes por parte dessas instituiçóes. A especificação compreende, assim, um conjunto de disposiçôes de regulação que, quando emitidas no plano nacional, tendem a produzir convergência entre municípios nos modos de inserçẫo dos conselhos no funcionamento regular da política, e, por conseguinte, nas atividades por eles desempenhadas. Tal convergência, bem como a expansão, guardam relação com a concentração da capacidade decisória na Uniáo, no que diz respeito ao desenho de políticas, e podem ser interpretadas, no quadro institucional geral das feiçóes do federalismo brasileiro, como constrangimento do escopo decisório dessas IPs, nos planos estadual e municipal (Cunha et al., 2020). ${ }^{5}$ Conforme será visto, graças à tipologia e sua capacidade de previsão da atuação dos conselhos, é a especificação institucional que os torna, todavia, ativos. E mais: os resultados aqui apresentados nos permitem argumentar que a especificaçáo institucional setorial pode também ocorrer em nível subnacional, produzindo divergência entre conselhos ao largo do território nacional.

Contrastar como as duas dimensóes - indução e especificação institucional - se comportam em casos concretos contribui para a compreensão de suas especificidades. Os emblemáticos Conselhos de Saúde, do primeiro grupo, constituem um exemplo de área em que se somaram, de um lado, mecanismos fortes de indução federal para expansão territorial (tal qual discutido acima) e, de outro lado, a existência de regulaçōes e normas operativas, também federais, que estabeleceram quais atividades essas instituiçôes 
subnacionais teriam que desempenhar, e como (Guicheney, 2019). Confira-se, de modo ilustrativo de tal especificação, o seguinte excerto de um documento de atualização e qualificação dos secretários de saúde estaduais (e suas equipes), elaborado pelo Conselho Nacional de Secretários da Saúde (CONASS) em parceria com o Ministério da Saúde: ${ }^{6}$

[...] o caráter deliberativo e permanente dos Conselhos pressupóe uma atuação constante para que seus membros tenham condiçóes de examinar e aprovar as diretrizes da política de saúde, formulando estratégias, aperfeiçoandoas e propondo meios aptos para sua execução e correção de rumos. O Conselho não pode ser transitório, ou seja, funcionar somente quando convocado, mas reunir-se, no mínimo, uma vez ao mês e extraordinariamente sempre que necessário. [...] Uma vez, a cada três meses, a pauta da reuniāo do Conselho deve incluir a prestação de contas feita pelo gestor da esfera de governo correspondente, que deverá, para tanto, apresentar relatório detalhado, contendo o andamento da agenda de saúde pactuada, o relatório de gestão, dados sobre o montante e a forma de aplicação dos recursos, as auditorias [...], entre outros. (Brasil, 2003, p. 59)

A comparação com o caso da Educação, do segundo grupo, fornece contraponto interessante. Se considerada a sua expansão territorial, os conselhos do setor seriam agrupados junto com os da Saúde. Neste caso, o salto no processo de expansão ocorre entre os anos de 1995 e 1996, e coincide com a promulgação das leis que, respectivamente, criam o Conselho Nacional de Educação (lei 9.131 Brasil, 1995) e incluem a participação nas diretrizes do sistema educacional (Lei 9.394 - Brasil, 1996) (Gurza Lavalle e Barone, 2015). Não obstante, diferentemente do caso da Saúde, os indícios de especificação institucional no setor de educação não são encontrados com igual facilidade. Não é possível identificar quaisquer alusóes a conselhos municipais ou estaduais na Lei que cria o Conselho Nacional, nem em seu regimento interno (Cury, 2006). Além disso, enquanto a Lei de Diretrizes e Bases faz referências ao
Conselho Nacional de Educação, sequer menciona os municipais. Há razóes para acreditar que orientaçóes mais incisivas, quanto à especificação do funcionamento dos Conselhos de Educação - se houver -, advêm do nível estadual. A esse respeito, Teixeira (2004) identifica, nas secretarias e nos conselhos estaduais, as principais fontes de orientação referentes à gestão municipal da educação. Assim, Conselhos de Educação contam com elevada capilaridade territorial, mas, ao menos do ponto de vista de sua especificação institucional via disposiçóes de nível federal, sua atuação na política seria aparentemente mínima (Souza e Vasconcelos, 2006).

Um exemplo adicional do segundo grupo são os Conselhos de Meio Ambiente: ainda que eles pertençam a uma política estruturada em um sistema nacional (o Sisnama), este é consideravelmente distinto dos arranjos institucionais de áreas mais consolidadas. Assim, se, por um lado, a área apresenta instituiçóes próprias de gestão em nível subnacional (órgão administrativo, secretaria, conselhos), além de burocracia local; por outro lado, o sistema ainda sofre de limitações de implementação: fragilidade institucional dos fóruns destinados à pactuação de políticas entre atores subnacionais, déficit de capacidade instalada e carência de recursos específicos (Leme, 2010). Particularmente quanto aos conselhos, não há disposições que tornem obrigatória sua criação nos municípios para o recebimento de transferências federais, mas existem mecanismos de inserção dessas IPs na política ambiental, sobretudo nas atividades de licenciamento ambiental.

A combinação das duas dimensôes (indução federal e especificação institucional) permite distinguir três tipos de conselhos, organizando analiticamente expectativas de convergência e divergência no que tange à existência dessas instituiçôes no território, bem como às funçôes por elas desempenhadas. Ambas as dimensões podem assumir expressão forte, moderada ou fraca, produzindo, em termos estritamente lógicos, uma matriz de nove combinaçóes possíveis $(3 \times 3)$. Não obstante, nem todas as combinaçôes lógicas são empiricamente relevantes e, de fato, as combinaçôes de interesse podem ser agregadas na configuração de apenas três tipos de conselhos. Assim, a tipologia não é expressão agregada de um exercício empírico 
de classificação, mas sim a expressão condensada de possibilidades lógicas empiricamente informadas. ${ }^{7}$ O Quadro 1, abaixo, articula ambas as dimensóes e apresenta a tipologia, fornecendo exemplos de como diferentes conselhos se distribuem em cada uma das três categorias. Em relaçáo ao contraponto entre os Conselhos de Saúde e Educação - acima explorado -, observe-se que: enquanto os primeiros integram o primeiro tipo (C1), os segundos estão situados em grupo intermediário (C2). Por sua vez, em C3 encontram-se os casos em que tanto a implantação, quanto a especificação dependem majoritariamente do nível municipal.

A tipologia de conselhos náo apenas ordena a sua presença territorial e especificação institucional, conforme o correspondente setor, como também define que eles estarão em melhores condições de incidir sobre as políticas, permitindo antever, para os fins do presente artigo, características médias esperadas de seu padrão decisório (volume e escopo). Espera-se que conselhos universalizados e bem inseridos no funcionamento regular da política tendam a ser mais ativos, ter maior capacidade de atuaçáo e apresentar maior homogeneidade entre si, quando da mesma área, no que diz respeito ao perfil de atuaçáo.

De modo mais específico, consideramos o número e escopo de decisóes tomadas por essas IPs como evidências, respectivamente, do volume de atividade e do perfil de sua atuação. O exame pormenorizado da produçáo decisória em diversas áreas ${ }^{8}$ mostra uma concentração de resoluções nos conselhos de tipo $\mathrm{C} 1$ - precisamente os mais difundidos e mais bem especificados institucionalmente-, em contraste com números reduzidos e pouco diversos em C3. Por sua vez, os aspectos qualitativos das decisóes reiteram o padrão: conselhos $\mathrm{C} 1$ e, em menor medida, $\mathrm{C} 2$,

\section{Quadro 1}

Tipologia de Conselhos

\begin{tabular}{|c|c|c|c|}
\hline $\begin{array}{l}\text { Tipos de } \\
\text { Conselho } \\
\end{array}$ & Indução federal $\left(^{*}\right)$ & $\begin{array}{c}\text { Especificaçáo Institucional } \\
\text { federal }(* *)\end{array}$ & Exemplos \\
\hline C1 & $\begin{array}{c}\text { Mecanismos fortes de } \\
\text { indução federal impulsionam } \\
\text { a expansão, resultando em } \\
\text { tendência à universalização } \\
\text { nos municípios. }\end{array}$ & $\begin{array}{l}\text { Institucionalmente } \\
\text { especificados, condicionando } \\
\text { processos regulares da política à } \\
\text { realização de funçóes por parte } \\
\text { dos conselhos. }\end{array}$ & $\begin{array}{c}\text { Saúde; Assistência Social; Criança e } \\
\text { Adolescente; Alimentação Escolar; } \\
\text { Fundef/Fundeb. }\end{array}$ \\
\hline $\mathrm{C} 2$ & $\begin{array}{l}\text { Mecanismos fortes ou } \\
\text { inconsistentes/moderados de } \\
\text { indução federal impulsionam } \\
\text { a expansão, resultando, } \\
\text { respectivamente, em tendência } \\
\text { à universalização ou à presença } \\
\text { mediana nos municípios. }\end{array}$ & $\begin{array}{c}\text { Institucionalmente não } \\
\text { especificados, ou com } \\
\text { especificação que não } \\
\text { condiciona processos regulares } \\
\text { da política à realização de } \\
\text { funçóes por parte dos conselhos. }\end{array}$ & $\begin{array}{l}\text { Educação; Conselho do Bolsa Família; } \\
\text { Cultura; Drogas; Habitação; Idoso; } \\
\text { Meio Ambiente; Trabalho/Emprego. }\end{array}$ \\
\hline C3 & $\begin{array}{l}\text { Mecanismos fracos ou } \\
\text { inexistentes de indução } \\
\text { federal, resultando em fraca } \\
\text { presença nos municípios }\end{array}$ & $\begin{array}{l}\text { Institucionalmente não } \\
\text { especificados. }\end{array}$ & $\begin{array}{l}\text { Agricultura; Ciência e Tecnologia; } \\
\text { Defesa do Consumidor; Deficiência; } \\
\text { Desenvolvimento Econômico; } \\
\text { Patrimônio; Desenvolvimento } \\
\text { Urbano; Direitos Humanos; Esporte; } \\
\text { Juventude; Mulher; Raça; Saneamento; } \\
\text { Segurança; Segurança Alimentar; } \\
\text { Transporte; Turismo. }\end{array}$ \\
\hline
\end{tabular}

(*) Indução federal para criação de conselhos nos municípios, em uma dada área de política. $\left.{ }^{*}\right)$ Especificação institucional federal para definição, mediante normatização, das funçôes que serão exercidas pelo conselho, em uma área de política.

Fonte: elaboração própria, a partir do banco de decisões e do banco de conselhos. Proj. Conselhos, Regimes Subnacionais e Capacidades Estaduais. CEM. 
apresentam concentração de decisões mais potentes, ligadas ao planejamento e à fiscalização da política (e.g.: aprovação de planos e orçamentos, análise de prestaçóes de contas do Executivo); enquanto conselhos de tipo C3 aparecem como instituiçóes inativas, ou concentrando decisões em autorregulação e desprovidas, portanto, de potencial direto de incidência sobre a política pública (Gurza Lavalle et al., 2016). Cumpre advertir que os padróes esperados não implicam que conselhos do mesmo tipo tomem resoluções semelhantes, mas tão somente que o potencial de incidência sobre a respectiva política seja maior ou menor, dependendo dos tipos de decisóes tomadas. ${ }^{9}$ Por fim, a associação entre maior volume de decisóes de caráter mais potente e conselhos $\mathrm{C} 1$ obedece à normatização setorial de nível federal, que também é capaz de produzir maior homogeneidade na atividade dos conselhos de um mesmo setor.

Os padróes convergentes esperados descansam na premissa da prevalência de regimes nacionais de normatização setorial. Porém, se a especificação institucional e os incentivos à expansão territorial dos conselhos ocorrerem em nível subnacional, a própria normatização setorial poderá ser responsável por produzir diferenciação em sua atuação, em um mesmo setor de políticas. Se assim acontecer, o conhecimento acumulado requerirá revisão, para assimilar a ocorrência de regimes subnacionais de regulação. ${ }^{10}$

\section{Padróes da atividade decisória dos conselhos}

\section{Decisóes como unidade analitica: coleta e classificação}

Por força de lei, as resoluçôes dos conselhos devem ser publicadas nos DOs de seus respectivos municípios, ainda que nenhuma norma de escopo nacional obrigue sua disponibilização em plataformas públicas online, nem discipline o formato ou a proporção do conteúdo total a ser divulgado. Levantamento para todos os municípios de mais de 20.000 habitantes - realizado por nossa equipe - constatou a inexistência e/ou indisponibilidade frequentes dessa publicação oficial, evidenciando a impossibilidade de construção de uma amostra aleatória de municípios. ${ }^{11}$ Optou-se, então, por uma amostra condicionada por disponibilidade. ${ }^{12}$

Decidiu-se amostrar casos que contassem com séries de DOs online, para o período de 7 anos delimitados pela pesquisa (2005-2011), ${ }^{13}$ no interior de uma lista de municípios ordenada de forma decrescente pelo tamanho da população. Tal delimitação buscou reduzir o papel de fatores associados ao porte que, segundo a literatura, podem acentuar a heterogeneidade entre conselhos e suas capacidades - conforme será visto. $\mathrm{Na}$ lista de cinco municípios selecionados, ${ }^{14}$ apenas Guarulhos não é capital de estado; contudo, para além dos fatores associados ao porte, já razoavelmente controlados, desconhecemos evidências dos efeitos de os municípios serem sede do governo estadual sobre as atribuiçôes e operação de seus conselhos setoriais. Além disso, a atividade decisória do conselho de Guarulhos é consoante ao padrão esperado

Após a seleção de municípios, realizou-se levantamento exaustivo de todos os conselhos e de todas as decisóes por eles publicadas, ao longo desses 7 anos, nos respectivos DOs locais. Foram identificadas 138 unidades, dentre as quais, 77 publicaram resoluçôes. ${ }^{15}$ Portanto, nosso banco de dados é extenso, pois é composto pelo censo das decisóes tomadas pelos conselhos ativos no período considerado. Trata-se de um corpus de 14.950 decisóes, que demandou três anos (2014-2017) de minucioso processo de leitura, compreensão, classificação, conferência e complementação de dados.

A tipificação das decisóes exigiu laboriosa classificação, checagem e reclassificação por sucessivas rodadas de verificação cruzada. A tipologia resultante desse processo ordena as resoluçôes dos conselhos em cinco tipos: ${ }^{16}$

- Definição: decisóes que incidem sobre os momentos de planejamento e definição de critérios gerais da política (exs.: aprovação/denegação de orçamentos e planos municipais ou da adesão a programas federais; definiçãao de critérios para prestação de contas de Organizaçóes da Sociedade Civil (OSCs));

- Fiscalização: decisões em que incidência ocorre após a implementação, a partir de expedientes de fiscalização e sanção de prestaçóes de contas (exs.: 
aprovação/denegação de prestação de contas de fundos setoriais, ou de relatórios de cumprimento de projetos do Executivo e de OSCs);

- Gestão: decisóes que incidem sobre a gestão da política (exs.: gestão da inscrição de OSCs e de parcerias e convênios com elas; aprovação/ denegação de obras e aquisiçóes de produtos e serviços pelo Executivo);

- Instituições participativas: decisóes que incidem sobre outras instituiçóes participativas (IPs), como conferências de políticas e conselhos tutelares, mas não somente (exs.: aprovação/denegação de regimento interno das instâncias; convocação de conferências);

- Autorregulação: decisóes dos conselhos relativas à gestão, organização e regramento de suas próprias atividades (exs.: regulamentação e supervisão das eleições para conselheiros; constituição de colegiados internos).

A tipologia de decisões permite caracterizar os padrōes da atividade decisória dos conselhos, evidenciando perfis de atuação associados a determinadas áreas de política. ${ }^{17}$ Conselhos, que majoritariamente tomam decisóes de autorregulação (sobre a eleição de conselheiros, por exemplo), dificilmente incidem na sua correspondente área de política e, do ponto de vista dos seus propósitos institucionais substantivos, são "decisoriamente" pouco produtivos. Por sua vez, conselhos com elevado número de decisões de gestão tendem a desempenhar papel ativo na operação da política. Em termos gerais, os três primeiros tipos de decisóes estão associados a um potencial maior de incidência sobre a política; enquanto nos dois últimos, esse potencial é menor ou, na melhor das hipóteses, muito indireto.

\section{Volume, escopo e dispersão}

Se o nosso exame dos tipos de conselhos for correto, os de primeiro tipo (C1) serão os melhores candidatos para a procura de padróes: (i) de maior atividade decisória (volume de decisões); (ii) com perfil menos orientado para a autorregulação ou para funções indiretas, e mais para a incidência direta sobre a política (escopo); e, por fim, (iii) com maior homogeneidade nos padróes decisórios entre conselhos do mesmo tipo, tanto em termos do número de decisóes, quanto de seu conteúdo (dispersão). Por sua vez, e no extremo oposto, conselhos do terceiro tipo (C3) deverão apresentar níveis de atividade mínimos, perfil de incidência acanhado e menor homogeneidade. Caberia aos de segundo tipo uma posição intermediária entre as características dos conselhos $\mathrm{C} 1$ e C3. Note-se que os padróes combinam três dimensões gerais da atividade decisória: quantidade (volume), qualidade (escopo) e variabilidade (dispersão). A relevância dos conselhos para a política comporta diversas combinaçóes possíveis, mas ela se incrementa quando tais combinações se deslocam no sentido do padrão esperado para o tipo $\mathrm{C} 1 \mathrm{e}$, inversamente, decresce quanto mais estas se aproximam do padrão esperado para o tipo C3.

Certamente, os padrôes convergentes esperados podem, ainda, acusar efeitos significativos de fatores extra-setoriais. Notadamente, a literatura argumentou que o porte dos municípios onde os conselhos são implantados não é indiferente quanto àquilo que fazem, nem quanto à qualidade da participação que neles ocorre, mesmo em se tratando de conselhos do mesmo setor (Almeida et al., 2016). ${ }^{18} \mathrm{O}$ efeito do porte é conhecido pela literatura de políticas públicas (Arretche et al., 2012) e remete a características sociodemográficas e econômicas dos municípios, encontrando-se, usualmente, acompanhado de outros aspectos tais como a dimensão dos problemas urbanos e sociais e/ou dos recursos financeiros, institucionais e humanos, localmente disponíveis. Neste artigo, o porte é mantido constante pela seleção dos municípios.

Nossa pesquisa logrou identificar, nos cinco municípios, 138 conselhos, dentre os quais, apenas 77 (55,8\%) foram considerados "ativos" quando utilizado um critério generoso de classificação: o de ter emitido (e publicado) ao menos uma decisão entre 2005 e $2011 .{ }^{19}$ Isso significa que os demais conselhos foram criados formalmente, mas não operavam no dia a dia (ao menos, não no período analisado). ${ }^{20}$ Como seria de se esperar, a proporção de conselhos inativos é crescente à medida que passamos da observação do tipo C1 $(9,8 \%)$ para C2 $(29,5 \%)$ e, então, para C3 $(60,7 \%)$. Tal resultado permite atentar para a fragilidade dos conselhos $\mathrm{C} 3$, mesmo em municípios que, graças a seu porte ( $>1$ milhão de habitantes), 
apresentariam, segundo a literatura, condições mais favoráveis para a implantação e amadurecimento dessas IPs. E mais: não há conselhos $\mathrm{C} 1$ inativos de Saúde, Assistência ou Direitos da Criança e do Adolescente, apenas de alimentação escolar e Fundef/Fundeb (estes últimos, em média, de criação mais recente).

Os 55,8\% ativos foram responsáveis pela produção de quase 15 mil decisóes, em sete anos. Em média, cada um deles teria publicado 27,7 atos administrativos/ano - valor, não obstante, pouco informativo, tendo em vista a existência de enorme variação na autoria desses atos (como se verá). Por ora, a Tabela 1 mostra que a distribuição das resoluções tomadas pelos diferentes tipos de conselhos (C1, C2 e C3) comporta-se seguindo padróes esperados e inesperados, além de evidenciar a variação supracitada. Por sua vez, o Gráfico 1 permite apreciar a estabilidade do padrão ao longo do tempo.

Se considerados os resultados agregados (todos os anos), apenas $5,7 \%$ das decisóes são publicadas pelo tipo C3, que, todavia, responde por $42,9 \%$ dos conselhos. A cifra dos C3, os mais dependentes da iniciativa municipal, reforça a compreensão de que eles se encontram fragilmente institucionalizados e de que, após criados, apresentam dificuldades para "sair do papel" e estabelecer rotinas de funcionamento mais regular - embora, como será visto, isso não signifique que, necessariamente, fracassarão as iniciativas locais para torná-los ativos mediante especificação institucional. No polo oposto, os conselhos C1 representam apenas $24,7 \%$ do número total de conselhos, mas são responsáveis por quase a metade $(47,3 \%)$ de todas as decisões tomadas naquele período. $\mathrm{O}$ padrão das proporçóes do número de decisóes entre tipos de conselhos permanece estável ao longo do tempo, com um incremento progressivo, exceto queda perceptível registrada em 2009 (Gráfico 1). Desconhecemos, por ora, as causas desse incremento, bem como da queda. ${ }^{21}$

Porém, um olhar cuidadoso revela resultados inesperados. Diante da expectativa de que conselhos mais difundidos e institucionalizados produzam mais resoluçóes do que os de categorias menos estruturadas, observa-se um quase "empate" entre conselhos $\mathrm{C} 1$ e C2 - cada uma delas publicou aproximadamente $47 \%$ do total de decisóes. Como visto na Tabela 1, isso obedece à concentração "anômala” de decisóes em conselhos C2, em Belo Horizonte (76,2\%) e Goiânia $(71,9 \%)$, e ao fato de que tais proporçóes escondem alguns poucos conselhos muito produtivos.

Examinando especificamente os números da capital mineira, por exemplo, é possível advertir que seu volume de resoluçóes representa nada menos do que $37 \%$ de todo o universo em análise - o que explicaria por si só as maiores discrepâncias. O município também concentra $81,5 \%$ da produção dos conselhos C3 no banco de decisóes. Como as duas dimensóes da tipologia de conselhos - indução e especificação institucional - são de nível federal, os resultados sugerem que a capacidade de os inscritos nos tipos $\mathrm{C} 2$ ou $\mathrm{C} 3$ desenvolverem rotinas institucionais, compatíveis com o volume de decisóes registrado em Belo Horizonte e Goiânia, decorre de fatores que operam no plano subnacional.

Os resultados recém-examinados ganham perfil mais nítido se considerados os setores de política -

Tabela 1

Distribuição Percentual de Decisóes (Volume) por Tipologia de Conselhos (C1, C2, C3) e Município 2005 a 2011

\begin{tabular}{ccccc}
\hline Municípios & $\mathbf{C 1}$ & $\mathbf{C 2}$ & $\mathbf{C 3}$ & Total \\
\hline Belo Horizonte & $14,4 \%$ & $76,2 \%$ & $9,5 \%$ & $\mathbf{1 0 0 , 0 \%}$ \\
\hline Fortaleza & $97,8 \%$ & $1,3 \%$ & $0,9 \%$ & $\mathbf{1 0 0 , 0} \%$ \\
\hline Goiânia & $28,0 \%$ & $71,9 \%$ & $0,1 \%$ & $\mathbf{1 0 0 , 0} \%$ \\
\hline Guarulhos & $80,5 \%$ & $12,7 \%$ & $6,8 \%$ & $\mathbf{1 0 0 , 0 \%}$ \\
\hline Porto Alegre & $95,4 \%$ & $2,8 \%$ & $1,8 \%$ & $\mathbf{1 0 0 , 0} \%$ \\
\hline Representa X\% do total de decisóes & $\mathbf{4 7 , 3 \%}$ & $\mathbf{4 7 , 1 \%}$ & $\mathbf{5 , 7 \%}$ & $\mathbf{1 0 0 , 0} \%$ \\
\hline Representa X\% do total de conselhos & $\mathbf{2 4 , 7 \%}$ & $\mathbf{3 2 , 5 \%}$ & $\mathbf{4 2 , 9 \%}$ & $\mathbf{1 0 0 , 0} \%$ \\
\hline
\end{tabular}

Fonte: elaboração própria, a partir do banco de decisões e do banco de conselhos. Proj. Conselhos, Regimes Subnacionais e Capacidades Estaduais. CEM. 


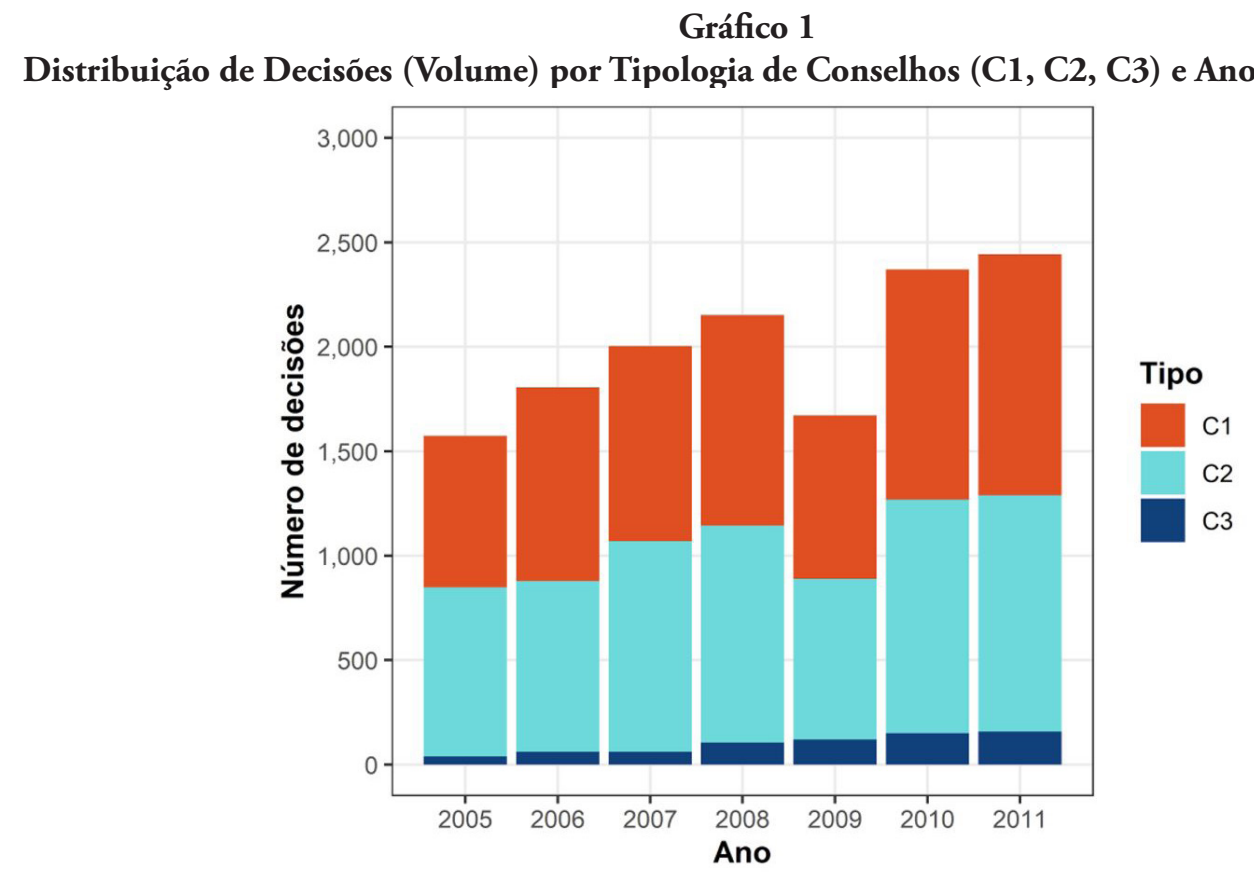

Fonte: elaboração própria, a partir do banco de decisōes e do banco de conselhos. Proj. Conselhos, Regimes Subnacionais e Capacidades Estaduais. CEM

a Tabela 2 mostra a distribuição das decisóes em relação a essa variável, por município. Cabe notar: nela, cada célula apresenta o percentual de decisóes emitidas por um único conselho, já que se trata de instituição de abrangência municipal. ${ }^{22}$

Ao lançar um olhar sobre a distribuição, no interior dos setores, é possível notar, em primeiro lugar, que apenas dez das áreas de política amostradas (dentre 31) representem $97,9 \%$ do total das decisōes sendo particularmente expressivas aquelas que comportam conselhos dos dois primeiros tipos, sobretudo as áreas de Assistência Social e da Criança e do Adolescente (ambos C1), e de Meio Ambiente e Educação (ambos C2).

Em segundo lugar, e ainda de acordo com a Tabela 2, é perceptível a distribuição mais homogênea de decisóes entre municípios nos Conselhos $\mathrm{C} 1$, conforme esperado. Notem-se os valores consideravelmente menores do coeficiente de variaçáo nesta categoria (0,56 para Assistência, 0,67 para criança e adolescente, e 0,84 para Saúde), considerando-se apenas os conselhos com presença em pelo menos quatro dos cinco municípios da amostra. Quando eliminada tal restrição, o coeficiente agregado é mais contrastante, com cifra menor para categoria $\mathrm{C} 1(0,8)$, contra valores consideravelmente maiores de $\mathrm{C} 2(3,0)$ e $\mathrm{C} 3(3,2)$. $\mathrm{E}$ mais: torna-se evidente, também, que as decisóes de alguns conselhos $\mathrm{C} 2 \mathrm{e} \mathrm{C} 3$ sequer estáo territorialmente distribuídas entre os diversos municípios. Basta observar os casos, em Belo Horizonte, de Meio Ambiente (concentra 99,2\% das decisōes), Patrimônio (98,7\%) e Desenvolvimento Urbano (97,4\%); e, em menor medida, de Educação, em Goiânia (61,6\%). O conselho belo-horizontino de Meio Ambiente, por exemplo, concentra, sozinho, não apenas a maior parte das resoluçôes dessa área de política, como também 22,5\% do universo de resoluçôes. Assim, no caso destes municípios, a alta produçáo decisória de conselhos C2 e C3 não pode ser atribuída à regulaçâo federal característica da respectiva área de política, restando hipoteticamente fatores explicativos quer de índole extra-setorial, quer setorial - porém, nesse último caso, operando em plano subnacional. Cumpre reiterar que não é gratuito o fato de a heterogeneidade acentuada entre municípios ocorrer precisamente nos conselhos C3 e C2, mas não nos C1.

A tipologia de decisóes, exposta na seção anterior, permite ir além do volume da atividade decisória e de 
Tabela 2

Distribuição Percentual de Decisóes por Área de Política, Município e Tipologia de Conselhos (C1, C2 e C3), com Apresentação do Coeficiente de Variaçáo por Área*

\begin{tabular}{|c|c|c|c|c|c|c|c|c|c|}
\hline \multirow{2}{*}{ Tipologia } & \multirow{2}{*}{ Áreas de política } & \multirow{2}{*}{$\begin{array}{c}\text { Coeficiente } \\
\text { de variaçáo }{ }^{* *}\end{array}$} & \multirow{2}{*}{$\mathbf{B H}$} & \multirow{2}{*}{ Fort. } & \multirow{2}{*}{ Goiânia } & \multirow{2}{*}{ Guar. } & \multirow{2}{*}{ PoA } & \multicolumn{2}{|c|}{ Total } \\
\hline & & & & & & & & $\%$ & $(N)$ \\
\hline \multirow{3}{*}{$\mathrm{C} 1$} & Assistência Social & 0,56 & 12,7 & 31,8 & 8,5 & 14,5 & 32,4 & 100,0 & 3.699 \\
\hline & Criança $\&$ adolesc. & 0,67 & 18,3 & 38,7 & 1,2 & 20,7 & 21,0 & 100,0 & 2.488 \\
\hline & Saúde & 0,84 & 14,1 & 14,9 & 13,4 & 7,8 & 49,8 & 100,0 & 918 \\
\hline \multirow{4}{*}{$\mathrm{C} 2$} & Meio Ambiente & 1,98 & 99,2 & 0,1 & 0,1 & 0,0 & 0,6 & 100,0 & 3.389 \\
\hline & Educação & 1,21 & 37,9 & 0,0 & 61,6 & 0,1 & 0,4 & 100,0 & 1.926 \\
\hline & Habitação & 1,66 & 78,4 & 0,7 & 0,7 & 15,1 & 5,0 & 100,0 & 139 \\
\hline & Idoso & 0,86 & 41,6 & 0,0 & 1,8 & 45,1 & 11,5 & 100,0 & 113 \\
\hline \multirow{3}{*}{$\mathrm{C} 3$} & Patrimônio & 1,97 & 98,7 & 0,0 & 0,7 & 0,5 & 0,1 & 100,0 & 1.297 \\
\hline & Desenv. urbano & - & 97,4 & - & - & 2,2 & 0,4 & 100,0 & 504 \\
\hline & Saneamento & - & 100,0 & - & - & - & - & 100,0 & 165 \\
\hline \multicolumn{5}{|c|}{ Demais áreas de política (produtoras de $\mathrm{N}<100$ decisóes) ${ }^{* * *}$} & & & & & 312 \\
\hline
\end{tabular}

$(*)$ Com o fim de aprimorar a visualização, nesta tabela foram incluídas apenas as decisóes tomadas por setores que produziram, individualmente, mais de 100 atos no período completo (2005-2011). Trata-se de 97,9\% das decisóes da amostra. (**) $\mathrm{O}$ coeficiente de variação foi calculado apenas para áreas de políticas que apresentaram conselhos em ao menos 4 dos 5 municípios da amostra; isto, porque sendo uma medida de dispersão, o indicador vai perdendo sentido à medida que há menos casos comparáveis. (***) Pertencem à categoria residual, neste caso, tanto conselhos C1, C2 ou C3 que produziram menos de 100 decisóes, quanto conselhos não classificados em C1, C2 ou C3.

Fonte: elaboração própria, a partir do banco de decisões. Proj. Conselhos, Regimes Subnacionais e Capacidades Estaduais, CEM.

\section{Tabela 3}

Média Anual de Atos Administrativos por Tipologia de Decisóes (Escopo) e Tipologia de Conselhos $(\mathrm{C} 1, \mathrm{C} 2, \mathrm{C} 3)^{*}$

\begin{tabular}{lccc}
\hline \multicolumn{1}{c}{ Tipos de decisáo* } & C1 & C2 & C3 \\
\hline Definiçấo de políticas & 4,8 & 3,2 & 1,0 \\
\hline Fiscalizaçáo de políticas & 5,0 & 4,4 & 0,0 \\
\hline Gestáo de políticas & 27,9 & 20,4 & 0,7 \\
\hline $\begin{array}{l}\text { Acerca de outras Instituiçóes } \\
\text { Participativas }\end{array}$ & 7,4 & 0,4 & 0,2 \\
\hline Autorregulação do conselho & 7,5 & 3,5 & 1,9 \\
\hline
\end{tabular}

(*) Os cálculos foram realizados a partir de $94 \%$ das decisōes, sendo o restante $(6 \%)$ referente aos casos da categoria residual, assim como aos valores missing.

Fonte: elaboração própria, a partir do banco de decisões. Proj. Conselhos, Regimes Subnacionais e Capacidades Estaduais, CEM.

sua dispersão entre conselhos de uma mesma área em diferentes municípios, e averiguar a relação entre os tipos de conselho e o escopo daquilo que é decidido.
O padrão é mostrado na Tabela 3, e sua distribuição mais detalhada ao longo do tempo pode ser apreciada no Gráfico 2. A primeira cifra a chamar a atenção na Tabela 3 é a comparativamente alta produção anual média de decisóes de Gestão Administrativa da parte de conselhos $\mathrm{C} 1$ e C2. No caso dos conselhos C1, essas decisôes envolvem, majoritariamente, a gestão da inscrição e do conveniamento de organizaçóes da sociedade civil implementadoras das políticas de Assistência Social e Direitos da Criança e do Adolescente. No caso dos conselhos $\mathrm{C} 2$ e C3, tais decisōes envolvem a gestão do credenciamento de escolas municipais, na área de Educação e, sobretudo, a gestão da utilização de imóveis tombados e áreas urbanas protegidas, no âmbito dos conselhos de Patrimônio Histórico e de Política Urbana, respectivamente.

Os conselhos $\mathrm{C} 1$ produzem um número médio anual de decisóes superior em todas as categorias, inclusive naquelas referidas à definiçâo, fiscalização e gestão, que, como vimos, denotam maior potencial de incidência sobre a política pública. Embora, cabe notar, 
com cifras não muito superiores às de conselhos $\mathrm{C} 2$ o que é facilmente explicável pelos padrōes reportados na Tabela 2 (sobretudo, a superproduçáo do Conselho de Meio Ambiente, que influencia a média global de C2). Em termos relativos, e pelo mesmo motivo, conselhos $\mathrm{C} 2$ concentram, proporcionalmente, um volume algo maior de decisōes de fiscalizaçáo. De outro lado, resoluçôes relativas a outras IPs são distintivas de Conselhos C1, em virtude, plausivelmente, da concentração de conferências nacionais e conselhos tutelares em seus correspondentes setores de política. Note-se que o padrão relativo do escopo decisório de C1 e C2 é estável ao longo do tempo (Gráfico 2).

As decisôes de Gestão Administrativa, em particular, têm sido amiúde criticadas pela literatura como evidência de um "perfil burocrático" ou mesmo "cartorial" dos conselhos, desviando-os daquelas que - em tese - deveriam ser suas reais funçōes, associadas a padrōes mais enfáticos de controle social. Trata-se, todavia, do exercício de atribuiçôes importantes de controle na operaçáo da política e na definiçấo dos provedores não estatais. Ademais, e de maneira interessante, os tipos de conselhos que mais concentram a produção das decisóes de Gestão $(\mathrm{C} 1$ e C2) são, ao mesmo tempo, aqueles que contam com a maior produção média de decisōes que implicam maior incidência sobre a política - Definição e Fiscalização da Política. Isto pode indicar que os processos de especificaçấo institucional, responsáveis por estabilizar o funcionamento dos conselhos por meio da atribuição de expedientes de gestão administrativa, não excluem, necessariamente, o tratamento de outros aspectos substantivos da política.

Por fim, os conselhos C3 apresentam padrão decisório rarefeito em todos os tipos de decisão (Tabela 3), e sua distribuição interna concentra, acentuadamente, mais atos administrativos de autorregulação do que outras categorias (Gráfico 2). Ademais, se comparado aos outros tipos de conselho, o padráo de C3 revela-se instável ao longo do tempo.

\section{Entendendo a "anomalia" e a conjectura de regimes subnacionais de normatizaçáo}

O conjunto de resultados, examinados na seção anterior, reitera um padráo duplo na atividade decisória dos conselhos, o qual requer elucidação. Duplo, pois, de um lado, evidencia o padrão geral esperado: aqueles verticalmente induzidos quanto à sua criação e cujas funções foram especificadas por normas setoriais _ são responsáveis pela emissão de

\section{Gráfico 2}

Distribuiçáo Percentual dos Atos Administrativos por Tipologia de Decisóes (Escopo), Tipologia de Conselhos (C1, C2, C3) e Ano da Publicaçáo (2005-2011)

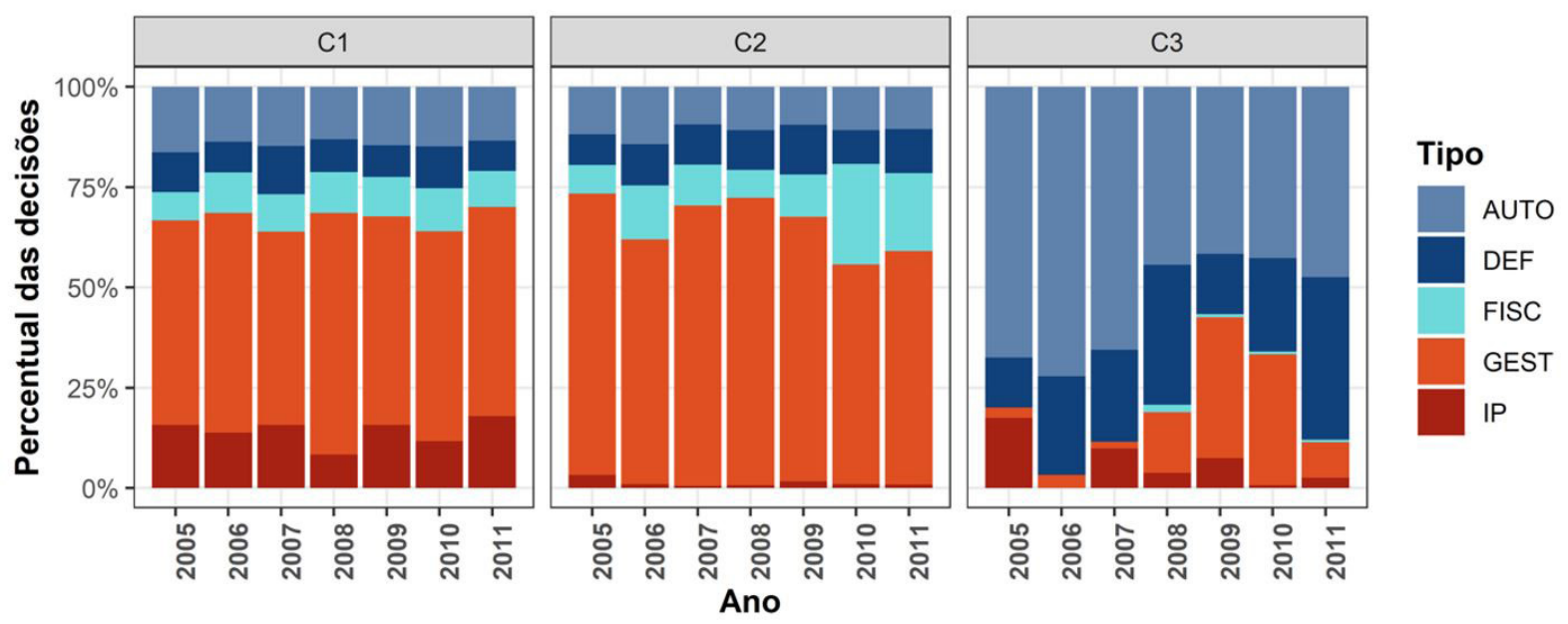

Fonte: elaboração própria, a partir do banco de decisóes e do banco de conselhos. Proj. Conselhos, Regimes Subnacionais e Capacidades Estaduais. CEM. 
um volume maior de decisões, com um escopo mais largo de funçōes e menor variabilidade _ quer dizer, mais homogêneo entre os conselhos de uma mesma área. De outro lado, porém, o mesmo conjunto de resultados revela, também, uma "anomalia", na medida em que acusa uma surpreendente hiperatividade decisória de poucos conselhos C2 e C3. Quanto ao caráter "anômalo" dessa hiperatividade, cabe lembrar que aqueles que são carentes de incentivos federais ficam - em tese - à mercê de vicissitudes da política e das políticas locais. O parco padrão decisório _ quando não, inatividade observado naqueles $\mathrm{C} 3$, sugere que tais vicissitudes são raras vezes favoráveis, e também mostra que a hiperatividade decisória detectada escapa ao comportamento considerado "normal" ou esperado para aquelas instituições.

Especificamente, e conforme mostrado na subseção anterior, alguns conselhos de Belo Horizonte como Meio Ambiente e Patrimônio , além do conselho de Educação, em Goiânia, escapam ao padrão esperado. Apreciação mais apurada de tal "anomalia" pode ser desenvolvida mediante procedimento duplo: primeiro, através da observação focada nesses conselhos, via incorporaçáo de dados sobre o potencial de incidência da atividade decisória; depois, por meio da procura de disposiçóes na regulação estadual, que possam estar positivamente associadas a seu caráter atipicamente ativo.

O potencial de incidência pode ser aferido como a proporçáo de decisóes emitidas com maior capacidade de incidência em políticas, em relação ao universo de decisóes. Assim, o Índice de Incidência em Políticas (IIP) considera apenas os atos mais claramente orientados para a definição e o controle de políticas; a saber, aqueles de definiçãao, fiscalização e gestáo da política. ${ }^{23} \mathrm{O}$ Gráfico 3 exibe os resultados do índice (variando entre as proporçôes 0,0 e 1,0). Cabe, aqui, uma nota explicativa: são apresentados valores para os conselhos de tipo $\mathrm{C} 2$ com e sem a inclusão do conselho de Meio Ambiente, de Belo Horizonte, objetivando permitir a comparação dos resultados com e sem o único caso de outlier na média do número de decisóes.

O comportamento esperado do índice de incidência é de que ele acompanhe a tipologia de conselhos, associando melhor desempenho àqueles de tipo C1. Conforme sugerido preliminarmente _pelo resultado da subseçáo anterior _ e como pode ser visto no Gráfico 3, conselhos C3 produzem decisóes com menor potencial de incidência na respectiva

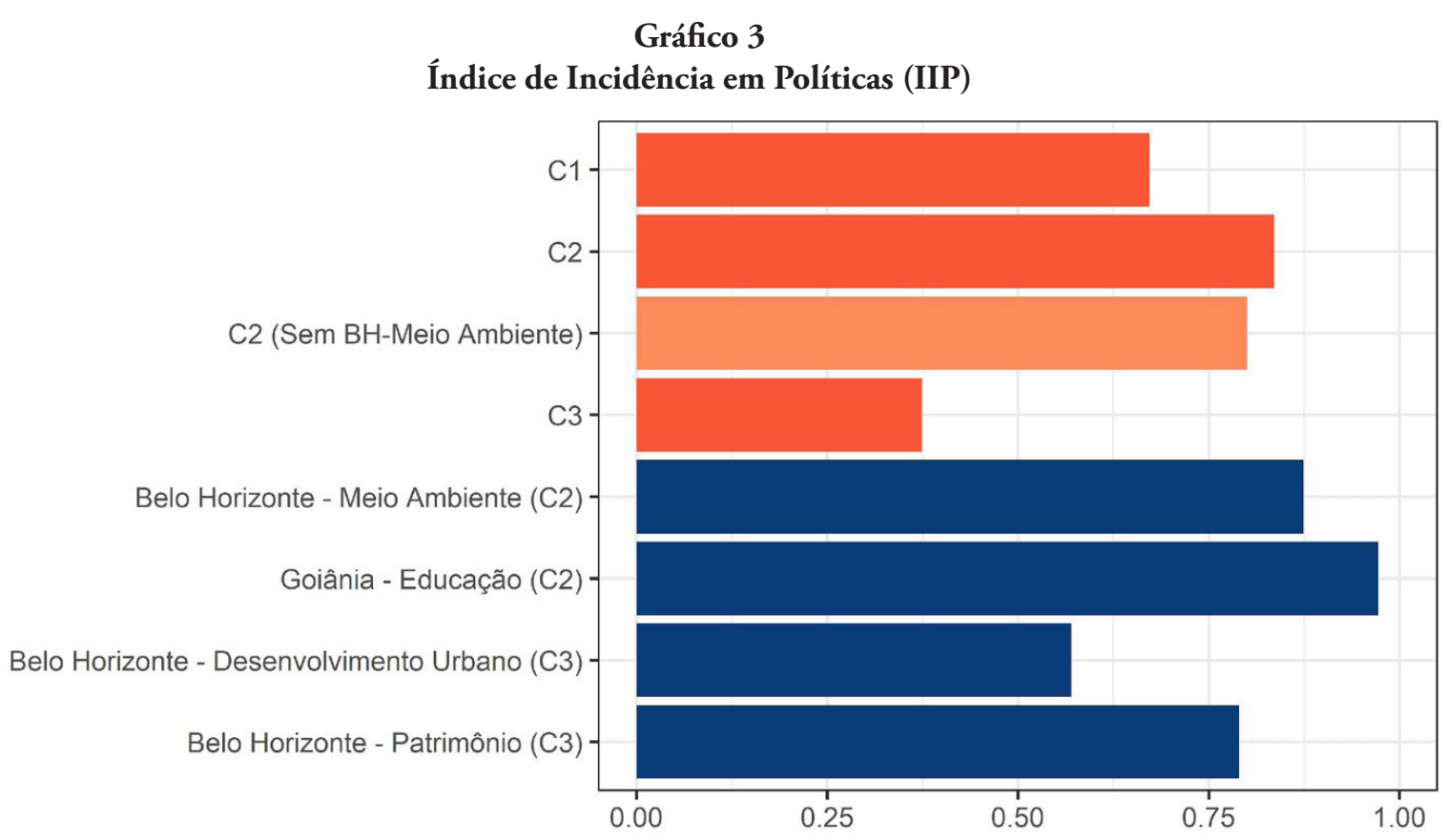

Fonte: elaboração própria, a partir do banco de decisóes. Proj. Conselhos, Regimes Subnacionais e Capacidades Estaduais, CEM. 
política. Isto, mesmo considerando que a média é favorecida ao incorporar as cifras dos conselhos de Desenvolvimento Urbano e Patrimônio, em Belo Horizonte, ambos com desempenho muito superior à média de C3. Por outro lado, precisamente os conselhos de Educaçáo e de Meio Ambiente (localizados em Goiânia e Belo Horizonte, respectivamente), ambos de tipo C2, são aqueles cujas decisóes apresentam maior potencial de incidência - acima da média dos conselhos $\mathrm{C} 1$ e $\mathrm{C} 2$. Cabe notar que o valor médio do tipo $\mathrm{C} 2$ é elevado pelos resultados desses dois conselhos, e, por conseguinte, se reduz quando retiramos da amostra o caso de Meio Ambiente. O padrão decisório "anômalo" desses conselhos C2 e C3 e sua concentração em Belo Horizonte e Goiânia sugerem, com base nos resultados descritivos apresentados, que municípios e/ou estados fazem diferença. É plausível conjecturar que - dentre os possíveis fatores associados a estados e municípios - normas definidas em níveis subnacionais afetam o papel desempenhado pelos conselhos em determinada política e, ainda, produzem a hiperatividade decisória observada.

A conjectura tem implicaçáo dupla. Primeiro, entendemos que, quando normas subnacionais constituem um arcabouço setorial específico de nivel estadual - capaz de afiançar institucionalmente os conselhos e conferir-lhes atuação distintiva em relação aos conselhos do mesmo setor, em outros estados-, opera um regime de normatização subnacional. Regimes estaduais produziriam, assim, maior heterogeneidade em relação à presença territorial e atuação de conselhos em estados distintos, e menor variaçáo relativa interna entre municípios de estados com tais regimes. Por sinal, regimes de normatização são conceitualmente mais restritos do que a ideia de regimes de regulação, de uso comum em diversas literaturas, uma vez que os segundos remetem a arranjos estáveis de órgãos, organismos, regras, atores e recursos, enquanto os primeiros foram aqui definidos em termos de normas ou regras. Em segundo lugar, e diferentemente, quando normas municipais potencializam a atuação de um conselho de determinado setor, o mesmo assume, quanto a sua atuação, características excepcionais, altamente contingentes, cuja apreensão seria difícil em termos da coerência interna de um conjunto de casos regulados de modo semelhante, que é própria à ideia de "regimes" ${ }^{24}$ Note-se que a variação derivada de normas municipais é possível, embora interesse, aqui, a ocorrência de regimes estaduais pela relevância de suas consequências agregadas.

Sem dúvida, fatores estaduais de outra natureza podem afetar a atividade decisória dos conselhos, explicando, em alguma medida, os resultados inesperados. Tal observaçáo coloca duas questóes incontornáveis: há evidências que sugiram a presença de regimes de normatizaçấo estadual? E, caso assim seja, como saber se outros fatores são responsáveis pela hiperatividade decisória verificada? É conveniente começar pelas evidências. Dentre os três casos mais destoantes, apresentados acima - Meio Ambiente e Patrimônio, em Belo Horizonte, além de Educação, em Goiânia -, focamos nos dois primeiros, para mostrar evidências favoráveis à conjectura; ou seja, à presença de regimes de normatização estadual. Selecionamos os dois casos por eles variarem na tipologia de conselhos (o primeiro é $\mathrm{C} 2$, o segundo, C3), mas permanecerem constantes no que diz respeito ao estado a que pertencem (de modo a reduzir a heterogeneidade dos casos). Embora ambos os conselhos sejam municipais, as evidências concernem, conforme indica a conjectura, à regulação e à trajetória da política estadual.

O Conselho Deliberativo do Patrimônio Cultural do Município de Belo Horizonte (CDPCM/BH), responsável pela segunda maior cifra de resoluçôes emitidas pelos conselhos nessa localidade, é expressão de uma estrutura administrativa estadual com legado de longa data no cuidado do patrimônio histórico (Bezerra, 2019). O estado de MG sedia uma das 27 superintendências do Instituto do Patrimônio Histórico e Artístico Nacional (Iphan), criada em 1971 sob a denominaçáo de Instituto Estadual do Patrimônio Histórico e Artístico de Minas Gerais (Iepha). ${ }^{25}$ Existe, ademais, um arcabouço administrativo estadual com atribuiçóes importantes, a exemplo do Conselho Estadual do Patrimônio Cultural (Conep), criado em 2007, com funçóes de decisão sobre a política, e, emblematicamente, do programa ICMS Patrimônio Cultural, que, desde 1995, tem incentivado fiscalmente a municipalização das políticas de proteção ao patrimônio ${ }^{26}$ levando à implantação, no estado, de mais de 700 conselhos municipais e 
600 fundos associados. ${ }^{27}$ Assim, a normatização e os incentivos estaduais conducentes à municipalização da política para o patrimônio parecem associados à hiperatividade do CDPCM/BH. ${ }^{28}$ Não é de se estranhar que mais da metade dos conselhos da área no país estejam sediados em Minas Gerais (IBGE, 2014). É improvável que tamanha concentração decorra das escolhas descoordenadas de prefeitos, em um estado conhecido por possuir o maior número de municípios no país (853).

Minas Gerais conta com uma proporção de Conselhos Municipais de Meio Ambiente superior à média dos outros estados brasileiros (77\% contra 66\%) (IBGE, 2013). Uma análise do histórico de institucionalização da política revela evidências que sugerem a presença de um regime de regulação estadual. Os conselhos estão no centro de estratégias de municipalização da política pelo menos desde a década de 1970. Iniciativas como o Programa de Cooperação Técnica com os Municípios para a Defesa do Meio Ambiente (Prodedam) e a Divisão de Apoio aos Municípios (Diamu), incluíram a criação de conselhos nas diretrizes que as prefeituras deveriam seguir, e também previram mecanismos de indução, tais como modelos de projetos de lei que pudessem ser utilizados em nível local para a fundação dos colegiados (Fundação João Pinheiro, 1996). Mais recentemente, tais estratégias evoluíram para mecanismos mais bem acabados de inserção dos conselhos na política ambiental, sobretudo nas atividades de licenciamento ambiental. A criação de conselhos é requisito para que o estado delegue aos municípios a sua competência de promover o licenciamento e fiscalização de empreendimentos potencialmente poluidores (Minas Gerais, 2016a; 2016b; 2017). É justamente nas ações de licenciamento ambiental que se encontram as principais atividades realizadas pelo Conselho de Meio Ambiente, em Belo Horizonte, o qual define critérios de licenciamento, concede as licenças, mobiliza audiências públicas para que atores com licenças aprovadas sejam escrutinados e, no caso de irregularidades, opera, também, como instância recursal. É relevante mencionar, ainda, que não somos os únicos a notar os efeitos da regulação estadual na expansão e atividade dos conselhos da área. ${ }^{29}$
Em suma, a convergência na atuação de conselhos inscritos em sistemas de política deriva da normatização federal própria ao respectivo setor, embora os conselhos possam estar sujeitos a mais de um regime de regulação. Ou seja, conselhos municipais estão efetivamente subordinados a normas federais, mas não somente. As evidências sugerem que regulaçóes de nível estadual são capazes de conferir aos conselhos - quando comparados a conselhos municipais do mesmo setor, em outros estados - maior presença territorial e especificação institucional mais potente, além de inseri-los mais ativamente no processo de operação regular da política.

No que diz respeito a possíveis fatores estaduais de outra natureza, certamente não é razoável esperar que a normatização estadual seja a causa única dos padrôes decisórios observados e, menos ainda, que ela se explique a si mesma - tampouco é este o argumento aqui sustentado. Sabe-se que o porte dos municípios - controlado razoavelmente pela seleção dos municípios contemplados - varia com a densidade populacional, o tamanho da economia e, por conseguinte, com a demanda de serviços públicos, a capacidade de arrecadação fiscal e outras capacidades estatais. Ademais, pela sua trajetória, setores de políticas se encontram associados a determinadas comunidades de políticas, compostas não apenas por burocracias com determinados perfil e compreensão do papel da participaçấo no respectivo setor, mas também por redes de atores privados e da sociedade civil - não raro com inserções regulares na provisão da política. Os padrões decisórios inesperados não parecem decorrer destes fatores gerais, pois, se assim fosse, eles deveriam afetar de modo semelhante aqueles conselhos de um mesmo setor ou de um dado porte.

Entretanto, fatores estaduais específicos podem incidir nos padróes observados, sendo prudente pensar que assim o fazem, ao menos de duas formas: ou determinando a criação dos regimes estaduais, e, nesse caso, os padróes decisórios e regimes responderiam, ambos, a um terceiro ou mais fatores comuns; ou incidindo juntamente com os regimes na atuação dos conselhos, contribuindo para a hiperatividade decisória observada. Na primeira possibilidade, por exemplo, o patrimônio histórico colonial de Minas Gerais associa-se à trajetória precoce da política 
patrimonial e ao fato de o estado concentrar mais da metade dos conselhos da área no país. Um argumento semelhante seria pertinente quanto à centralidade da mineração na economia do estado e seu legado de externalidades desastrosas sobre o meio ambiente. No segunda possibilidade, para mencionar apenas três fatores conhecidos, tem-se a predominância e perfil dos partidos políticos no executivo estadual, as capacidades estatais técnico-administrativas em determinado setor de políticas, e as capacidades de ação de redes temáticas da sociedade civil.

\section{Conclusóes e implicaçóes}

Com base no levantamento mais abrangente de que temos notícia - segundo o melhor de nosso conhecimento -, este artigo apresenta resultados inéditos sobre os padrốes da atividade decisória de conselhos gestores de políticas, em municípios de grande porte. Os resultados ampliam o conhecimento disponível sobre os conselhos e sua atividade decisória. Há ganhos cognitivos de duas índoles: resultados esperados e inesperados.

Grosso modo, os ganhos cognitivos no plano dos resultados esperados são confirmatórios. O perfil da atividade decisória da maioria dos conselhos, nos municípios de grande porte examinados, reforça a capacidade preditiva da tipologia de conselhos, além de verificar a correção das proposiçóes consolidadas na literatura, que descansam na importância dos setores de política e em seus fatores associados. Assim, conselhos C1 são especialmente ativos na emissão de resoluçóes, apresentam repertório de decisōes com escopo amplo e potente - proporcionalmente menos orientado para a autorregulação - e maior homogeneidade ou convergência entre si, quanto à atividade decisória. Por sua vez, conselhos $\mathrm{C} 3$ apresentam cifras elevadas de inatividade, baixa produção decisória, maior concentração proporcional de decisóes dedicadas à autorregulaçáo, bem como maior dispersão no volume de decisões entre conselhos de uma mesma área, nos diferentes municípios. A maioria dos conselhos C2 encontra-se, como prognosticado, distante dos conselhos $\mathrm{C} 1$ e, por vezes, próxima dos resultados dos conselhos C3, embora com cifras superiores.
Entretanto, o portentoso volume de decisóes de conselhos como o de Patrimônio e Meio Ambiente, em Belo Horizonte, ou Educaçẫo, em Goiânia, constitui uma "anomalia". O volume de decisōes informa que esses conselhos de tipo $\mathrm{C} 2$ e C3 encontram-se inseridos no funcionamento regular da política - e o exame da incidência potencial em políticas assim o indica. A hiperatividade desses conselhos obedece a fatores que escapam à indução e à especificaçâo institucional de origem federal e, conforme argumentamos, parecem operar em nível estadual. Conjecturamos que regimes de normatizaçấo estadual são responsáveis pelos padróes anômalos encontrados. $\mathrm{O}$ exame da regulaçáo estadual dos dois conselhos examinados sugere que nosso argumento tem fundamento. Certamente, as evidências da presença de regimes de regulação estadual são indícios, e não provas. Embora o porte dos municípios permaneça relativamente constante nos cinco municípios, outros fatores socioeconômicos - de índole extra-setorial - poderiam ser responsáveis pelos resultados não esperados. Ademais, os padrôes decisórios examinados correspondem a municípios específicos, restando possível que fatores locais - e não somente estaduais - também sejam responsáveis por tais resultados. Os próximos passos do projeto de pesquisa que originou os resultados aqui apresentados avançarão em duas direçôes: dialogando com a literatura de governança multinível, em relaçáo à caracterização de regimes de normatização subnacionais; e desenvolvendo argumento causal sobre a presença e os efeitos desses regimes na atuação dos conselhos, com base em dados de cobertura nacional.

Quais são as implicaçôes da existência de regimes de normatizaçáo subnacional para o estado da arte sobre os conselhos? Primeiro, ela indica que a descrição standard, centrada nos conselhos de políticas sociais e fortemente informada por uma narrativa focada no plano nacional, requer correçôes. Tal descrição corresponde a uma parte significativa dos conselhos, mas escapa-lhe um conjunto deles, animado por regimes estaduais, relevante pelos seus efeitos nas políticas e que permanece pouco pesquisado. Em segundo lugar, mecanismos estaduais de indução - como ICMS Patrimônio Cultural - e normas estaduais de especificação institucional podem estimular nâo só a difusão estadual e a atividade 
decisória dessas instituições, como também fomentar a sua estabilização e o desenvolvimento de rotinas institucionais, plausivelmente associadas inclusive, de modo positivo à̀ sua resiliência institucional. Assim, em contexto nacional especialmente adverso, a atuação de conselhos inscritos em regimes estaduais, não apenas daqueles tradicionais $(\mathrm{C} 1)$, parece contar com capacidade de resiliência.

Por fim, a existência de regimes de normatização subnacional constitui campo de pesquisa praticamente inexplorado. Que outros fatores, além da regulação estadual, propiciam a constituição de regimes subnacionais? Como eles se relacionam com trajetórias específicas de governança das políticas em questão? Ou qual a variedade de regimes e como eles variam na produção de efeitos sobre os conselhos? Os próximos passos assinalados acima orientam-se à comprovação da conjectura e generalização empírica da presença de regimes de normatização subnacional, considerando os últimos como fator explicativo da presença territorial e atuação dos conselhos. Resta em pé, também, o exame dos processos responsáveis por produzir tais regimes em determinados estados. Enfim, existem diversas perguntas esperando por respostas. Abraçálas, produzindo evidências sistemáticas, é desafio que demanda esforços coletivos. Esperamos que estas páginas estimulem o trabalho de pesquisa na confluência dos campos de estudos da participaçáo e de políticas públicas - campos estes, que têm mostrado vitalidade e notável capacidade de adensar agendas de pesquisa.

\section{Agradecimentos}

Este paper se inscreve nos resultados do projeto "Conselhos, Regimes Subnacionais e Capacidades Estatais", levado a cabo no interior do Centro de Estudos da Metrópole (CEM). Os autores agradecem o financiamento do CEM, processo no 2013/07616-7, e da Fundação de Amparo à Pesquisa do Estado de São Paulo (Fapesp). As opinióes, hipóteses, conclusões e recomendações aqui expressas são, porém, de responsabilidade dos autores e não refletem necessariamente a visão da Fapesp.

Os autores também agradecem as sugestôes dos pareceristas anônimos, bem como os comentários de
Rogério Arantes e dos colegas que participaram do IV Seminário Conjunto do CEM (março/2018), e, ainda, as críticas e sugestóes recebidas no XI Congresso da ABCP e no $42^{\circ}$ Encontro Anual da ANPOCS neste último caso, especialmente à contribuição de Roberto Pires. Restam agradecimentos a Carla Bezerra e Fernando Rodrigues, pelas críticas pertinentes e ajuda na apuração de informaçôes setoriais, bem como aos demais colegas envolvidos na produção do banco de dados (ver nota detalhada na seção metodológica). Por fim, ressaltamos a importância do Conselho Nacional de Desenvolvimento Científico e Tecnológico ( $\mathrm{CNPq})$, na qualidade de financiador das bolsas de pós-graduação de dois dos três autores ambos, hoje, com títulos já obtidos. Bruno Grisotto Vello agradece ao CEM e ao Cebrap, instituições às quais esteve filiado durante o desenvolvimento da pesquisa que originou o presente paper.

\section{Notas}

1 Resoluçóes são normalmente entendidas como decisóes de órgáos colegiados, mas alguns conselhos utilizam o termo para se referir apenas a um tipo específico de decisão ou a um ato administrativo. Aqui, os três termos serão utilizados de modo intercambiável.

2 Além dos três autores deste artigo, a equipe responsável pela coleta e tratamento dos dados também foi composta, ao longo da pesquisa, por Fernando Rodrigues, Ariana Monteiro, Augusto Salgado, Jéssica Voigt e Ceumar Mendonça. Lizandra Serafim e Osmany Porto contribuíram para o caso-piloto, Guarulhos, em projeto anterior (cf. Gurza Lavalle et al., 2016).

3 Para uma referência precoce aos efeitos da indução federal, ver os trabalhos de Carvalho (1998) e de Arretche (2012).

4 Gurza Lavalle et al. (2016) assumem essa conexáo demasiado próxima entre expansão e inserção regular dos conselhos no funcionamento da política. Ao ampliar a variabilidade do universo observado, no estudo comparativo entre municípios, a incorreção de tal associação tornou-se evidente.

5 O argumento dos regimes de normatizaçáo subnacional introduz qualificaçáo relevante ao debate sobre o federalismo no país, em linha de continuidade com os argumentos iniciados alhures (Gurza Lavalle et al., 2019), e explorados teoricamente na pesquisa em curso, em diálogo com a literatura de governança multinível. 
6 A iniciativa faz parte do Programa de Informação e Apoio Técnico às Novas Equipes Gestoras Estaduais do SUS, de 2003 (Progestores).

7 As evidências que animaram o desenvolvimento da tipologia provêm de diagnóstico sobre os padróes de expansão territorial dos conselhos no país (Gurza Lavalle e Barone, 2015), mas, já em sua primeira formulação (Gurza Lavalle et al., 2016) - aqui corrigida e aprimorada com o acréscimo de uma segunda dimensão, a especificação institucional -, ela foi elaborada em registro analítico dedutivo.

8 Explorado alhures (Gurza Lavalle et al., 2016).

9 Pesquisas têm mostrado variação naquilo que os conselhos decidem substantivamente. Conselhos de Saúde (C1) podem ser associados ora a resoluções de fiscalização sobre a prestação de contas por parte da prefeitura (Gonçalves et al., 2013), ora à definição de aspectos substantivos da política (Guicheney, 2019), ou ainda, à expressão de posicionamentos políticos, recomendações e declaraçôes de repúdio. Por sua vez, Conselhos de Assistência Social e de direitos da criança e adolescente - também de tipo $\mathrm{C} 1$ - concentram decisóes na gestáo do registro e dos convênios de organizaçôes da sociedade civil, provedoras de serviços (Menicucci, 2010; Cunha, 2010).

10 Vello (2018), utilizando parte do banco de dados de decisóes aqui empregado, mas para estudar a posiçấo dos conselhos em redes de controle social e accountability (web of accountability), apontou a possível existência de regimes federais, estaduais e, inclusive, municipais, de controle horizontal de políticas. Aqui, o foco é distinto e mais amplo: consideramos todas as decisóes tomadas por conselhos e avaliamos os regimes pelo potencial de incidência nas políticas, enquanto Vello considera decisóes de accountability e avalia o tipo de atores que eles visam controlar.

11 Verificamos que uma parcela pequena de prefeituras disponibilizava seus diários oficiais em formato digital e online. Ademais, tal distribuição era bastante desigual pelo território e ao longo do período coberto pela pesquisa.

12 Mesmo em municípios que contavam com DOs, foram excluídos aqueles que, no momento da coleta: i) náo disponibilizassem essas publicaçóes para todo o período amostrado, a exemplo de Salvador e Rio de Janeiro; ii) não apresentassem, nesses DOs, as resoluçôes integrais, mas apenas trechos, a exemplo de Brasília e de São Paulo; iii) apresentassem, em parte, publicaçôes inacessíveis para coleta, como Recife.

13 O levantamento piloto, no município de Guarulhos, visou cobrir um período em que houvesse dois mandatos - Eloi Pietá (2005-2008) e Sebastião Almeida (2009-
2012) - para observar eventuais mudanças nos padróes decisórios (Gurza Lavalle et al., 2016). A incorporação dos novos municípios, na fase seguinte da pesquisa, manteve, então, o mesmo recorte, já que a identificação e classificação manual das resoluçôes dos conselhos revelaram-se muito demandantes em termos de tempo e trabalho. A ampliação do período coberto (até 2020), mediante levantamento automatizado, faz parte da nova fase da pesquisa, hoje em andamento.

14 População variando, nesses municípios, entre 2.476.589 e 1.233.436 habitantes ( $5^{\circ}$ a $13^{\circ}$ posiçôes). Por sua vez, produto interno bruto [PIB (1.000,00 R \$)] variando entre $R$ \$ 66.315.192,00 e $R$ \$ 41.394.561,00 (4\% a $17^{\circ}$ posiçóes). Os dados são de 2011, ano mais recente de publicaçấo das decisôes aqui analisadas. Fonte: IBGE, 2018. www.ibge.gov.br/estatisticas-novoportal/ economicas/contas-nacionais/9088-produto-internobruto-dos-municipios.html? \&t=o-que-e.

15 Ver Anexo 1, para listagem completa dos conselhos analisados, por município e setor.

16 Dentro de cada um dos cinco tipos, a análise mais aprofundada da matéria das decisóes deu origem a diversos subtipos, não explorados neste artigo. Para detalhamento, ver Anexo 2.

17 A atuação dos conselhos pode ser observada pelos seus efeitos, em vez de pelas suas decisóes. Este é o foco da agenda da efetividade das IPs, no país (Pires, 2011; Pires e Vaz, 2010; Avritzer, 2010) e no exterior. Para as vantagens metodológicas de focar na tomada de decisôes (outputs) dos conselhos, em vez de investir em seus efeitos sobre a política (outcomes), ver Gurza Lavalle (2011).

18 A maturidade ou momento no ciclo de vida dos conselhos constitui outro fator extra-setorial já considerado pela literatura (Avelino et al., 2014; Gurza Lavalle et al., 2016).

19 No Anexo 1, há, também, a listagem completa dos conselhos inativos.

20 Alternativamente, poderiam ter deixado de publicar suas decisóes no DO local.

21 "Palpites informados" são possíveis: o amadurecimento dos conselhos tem sido apontado na literatura como um fator de incremento no número e escopo das decisóes (Avelino et al., 2014; Gurza Lavalle et al., 2016). Quanto à queda, repare-se que ela náo coincide com as eleiçóes presidenciais, as quais não acusam efeito no gráfico.

22 Ou seja, não pode haver, por exemplo, dois Conselhos de Saúde num mesmo município.

23 O cálculo do IIP e do IProd foi definido alhures (Gurza Lavalle et al., 2016). Não obstante, devido ao acúmulo 
de conhecimento ao longo da pesquisa, utilizamos aqui uma versão modificada e corrigida de IPP.

24 A variação na atuação dos conselhos derivada da política municipal foi identificada alhures (Gurza Lavalle et al., 2016).

25 http://www.iepha.mg.gov.br/index.php/institucional/oiepha\#hist $\%$ C3\%B3ria

26 http://www.iepha.mg.gov.br/index.php/programas-eacoes/icms-patrimonio-cultural\#o-que-\%C3\%A9.

27 https://www.ultimasnoticias.inf.br/noticia/institutodo-patrimonio-historico-e-artistico-inicia-a-6a-rodadaregional-do-icms-cultural/

28 No banco de dados há mais um município de Minas Gerais, Contagem, mas não foi incluído na presente análise por ser de porte comparativamente menor. Não obstante, Contagem também apresenta volume de resoluçôes muito acima da média para a área de políticas do Conselho.

29 Leme observa que: "Enquanto a média de crescimento [do número de conselhos de meio ambiente nos municípios] foi de $14 \%$, somente o Estado do Ceará teve um acréscimo de $47 \%$, passando de apenas 28 municípios com conselho para 115. Este expressivo resultado pode ser explicado pelo estímulo dado à criaçáo e ao fortalecimento de conselhos por programas como o Selo Verde, do órgáo estadual de meio ambiente, e o Programa Nacional de Capacitação de Gestores Ambientais e Conselheiros Municipais, do MMA [Ministério do Meio Ambiente], em parceria com a Associação de Municípios e com o órgão estadual de meio ambiente. No Rio Grande do Sul, há uma tradicional política de fortalecimento da gestão ambiental municipal, isso se traduz no estado com o maior percentual de conselhos municipais do país (80\%) [em 2008]" (Leme, 2010).

30 Além destes 77 conselhos que publicaram decisões no período, também registramos os 61 que foram considerados "inativos", por nâo serem autores de decisóes naqueles DOs, mas apenas sujeitos de decisōes de outras instituiçôes. Isto significa que eles foram criados formalmente, mas não operavam no dia a dia - ao menos, não no período analisado. Alternativamente, poderiam ter deixado de publicar suas decisões no DO local. Entretanto, tais conselhos não são explorados no presente texto.

\section{REFERÊNCIAS}

ALMEIDA, Carla; CARLOS, Euzeneia; SILVA, Rafael. (2016), "Efetividade da participação nos conselhos municipais de assistência social do
Brasil". Opiniāo Pública, 22, 2: 250-285. doi. org/10.1590/1807-01912016222250.

ALMEIDA, Carla; CAYRES, Domitila Costa; TATAGIBA, Luciana. (2015), "Balanço dos estudos sobre os conselhos de políticas públicas na última década”. Lua Nova, 94: 255-296. doi.org/10.1590/0102-64452015009400009.

ARRETCHE, Marta. (2012), Democracia, federalismo e centralização no Brasil. Vol. 1. Rio de Janeiro, Fundação Getúlio Vargas/ Fiocruz.

ARRETCHE, Marta, CORDEIRO, Berenice de Souza, FUSARO, Edgard Rodrigues, DIAS, Edney Cielici \& BITTAR, Mariana. (2012), Capacidades administrativas dos municipios brasileiros para a politica habitacional. Brasília/ São Paulo, Ministério das Cidades/ CEM.

ARRETCHE, Marta; VAZQUEZ, Daniel Vazquez; FUSARO, Edgard Rodrigues. (2007), Capacidades administrativas, déficit e efetividade na politica habitacional, Brasília/ São Paulo, Ministério das Cidades/ CEM.

AVELINO, George; BARBERIA, Lorena G.; BIDERMAN, Ciro. (2014), "Governance in managing public health resources in Brazilian municipalities". Health Policy and Planning, 29, 6: 694-702. doi.org/10.1093/heapol/czt003.

AVRITZER, Leonardo. (2010), A dinâmica da participação local no Brasil, São Paulo, Cortez.

VALENÇA, Maria Manoela; BAPTISTA, Myrian Veras; PEZOTI, Rosangela H.. (2002), Uma aproximaçẫo ao Conselho Municipal dos Direitos da Criança e do Adolescente do Município de São Paulo, São Paulo, Instituto Pólis/ PUC-SP.

BEZERRA, Carla. (2019), "Relatório de pesquisa 'Conselhos e regimes estaduais na política de proteção do patrimônio cultural'”, São Paulo, CEM/Cepid.

BOULDING, Carew \& WAMPLER, Brian. (2010), "Voice, votes, and resources: evaluating the effect of participatory democracy on well-being". World Development, 38, 1: 125-135. doi.org/10.1016/j. worlddev.2009.05.002. 
BRASIL. (1993), Lei no 8.742, de 7 de dezembro de 1993. Dispóe sobre a organização da Assistência Social e dá outras providências.

BRASIL. (1995), Lei no 9.131, de 24 de novembro de 1995. Instituiu o Exame Nacional de Cursos (ENC).

BRASIL. (1996), Lei no 9.394, de 20 de dezembro de 1996. Estabelece a lei de diretrizes e bases da educação nacional.

BRASIL. (2005), Lei $\mathrm{n}^{\circ} 11.124$, de 16 de junho de 2005. Dispóe sobre o Sistema Nacional de Habitação de Interesse Social - SNHIS, cria o Fundo Nacional de Habitação de Interesse Social - FNHIS e institui o Conselho Gestor do FNHIS.

BRASIL. (2003). Conselho Nacional de Secretários de Saúde (CONASS). Para entender a gestão do SUS / Conselho Nacional de Secretários de Saúde. Brasília.

CARVALHO, Antônio Ivo de. (1998), "Os conselhos de saúde, participação social e reforma do Estado". Ciência \& Saúde Coletiva, 3, 1: 23-25. doi.org/10.1590/1413-812319983102562014.

CÔRTES, Soraya Maria Vargas. (2002b), "Construindo a possibilidade da participação dos usuários: conselhos e conferências no Sistema Único de Saúde". Sociologias, 7: 18-49. doi.org/10.1590/ S1517-45222002000100002.

CÔRTES, Soraya Maria Vargas. (2002a). "Participação de usuários nos conselhos municipais de saúde e de assistência social de Porto Alegre", in R. Perissinotto \& M. Fuks (org.), Democracia: Teoria e Prática, Rio de Janeiro, Relume Dumará.

CÔRTES, Soraya Maria Vargas; SILVA, Marcelo Kunrath; REIS, Janete C.; BARCELOS, Márcio. (2009), "Conselho Nacional de Saúde: histórico, papel institucional e atores estatais e societais", in S. M. V. Côrtes (org.), Participação e Saúde no Brasil, Rio de Janeiro, Fiocruz.

CÔRTES, Soraya Maria Vargas. (2015), "Policy community defensora de direitos e a transformação do Conselho Nacional de Assistência Social". Sociologias, 17, 38: 122-154. doi.org/10.1590/15174522017003806 .
CUNHA, Eleonora Schettini Martins. (2010), "Inclusão social e política: o desafio deliberativo dos conselhos municipais de assistência social", in L. Avritzer (org.), A dinâmica da participação local no Brasil, São Paulo, Cortez.

CUNHA, Edite da Penha; LINS, Isabella Lourenço; SOARES, Márcia de Miranda. (2020), "Federalismo e conselhos de assistência social: uma análise a partir do financiamento". Opiniäo Pública, 26, 1: 127-157. doi.org/10.1590/1807-01912020261127.

CURY, Carlos Roberto Jamil. (2006), "Conselhos de educação: fundamentos e funçôes". Revista Brasileira de Política e Administração da Educação (RBPAE), 22, 1: 41-67. doi.org/10.21573/ vol22n12006.18721.

DONAGHY, Maureen M. (2011), "Do participatory governance institutions matter? Municipal Councils and Social Housing Programs in Brazil". Comparative Politics, 44, 1: 83-102. doi.org/10 .5129/001041510X13815229366606.

FERRARI, Sérgio. (2016), "Criação de municípios e debate científico: entre mitos e métodos". Revista de Informaçâao Legislativa (RIL), 53, 211:55-80.

FUNDAÇÃO JOÃO PINHEIRO. (1996), A questão ambiental em Minas Gerais: discurso e politica, Belo Horizonte, Centro de Estudos Históricos e Culturais.

GONÇALVES, Rodrigo de Souza; HAYAKAWA, Rogério Itsuo; GONÇALVES, Andréa de Oliveira; SERRANO, André Luiz Marques. (2013), "Conselhos de saúde e controle social: um estudo comparativo dos relatórios de prestação de contas das secretarias estaduais de saúde". Saúde e Sociedade, 22, 4: 1001-1013. doi.org/10.1590/ S0104-12902013000400004.

GUICHENEY, Hellen. (2019), Provisão municipal de bem-estar social: $O$ papel dos conselhos sobre a gestão, fiscalização e definição de politicas e serviços no plano local. Tese de doutorado. Faculdade de Filosofia, Letras e Ciências Humanas da Universidade de São Paulo, São Paulo.

GURZA LAVALLE, Adrian. (2011), "Participação: valor, utilidade, efeitos e causa”, in R. R. C. Pires 
(org.), Efetividade das instituiçóes participativas no Brasil: estratégias de avaliação, Brasília, IPEA. GURZA LAVALLE, Adrian \& BARONE, Leonardo Sangali. (2015), "Conselhos, associaçóes e desigualdade", in Marta Arretche (org.), Trajetórias das desigualdades: como o Brasil mudou nos últimos cinquenta anos, São Paulo, Unesp/ CEM.

GURZA LAVALLE, Adrian; VOIGT, Jessica; SERAFIM, Lizandra. (2016), "O que fazem os conselhos e quando o fazem? Padróes decisórios e o debate dos efeitos das instituiçóes participativas". Dados, 59, 3: 609-650. doi.org/10.1590/00115258201687.

GURZA LAVALLE, Adrian; RODRIGUES, Maira; GUICHENEY, Hellen. (2019). “Agência local e indução federal: a operação da política municipal de habitação em Recife e Curitiba”. Revista de Sociologia e Politica, 27, 71: e003. doi. org/10.1590/1678-987319277103.

IBGE. Pesquisa de Informações Básicas Municipais. 2013. Disponível em: ftp://ftp.ibge.gov.br/ Perfil_Municipios/2013/

IBGE. Pesquisa de Informações Básicas Municipais, Suplemento de Cultura, 2014.

IPEA, Instituto de Pesquisa Econômica Aplicada. (2010), "Instituiçôes participativas e políticas públicas no Brasil: características e evolução nas últimas duas décadas", in J. C. Cardoso Jr. (org.), Brasil em desenvolvimento: Estado, planejamento e políticas públicas, vol. 3, Brasília, IPEA.

LEME, Taciana Neto. (2010). "Os municípios e a política nacional do meio ambiente". Planejamento e Políticas Públicas, 35, jul./dez: 25-52.

MARICATO, Ermínia. (2006), “O Ministério das Cidades e a Política Nacional de Desenvolvimento Urbano”. Políticas Sociais (IPEA), 12: 211-220.

MENICUCCI, Telma Maria Gonçalves. (2010), “A política para crianças e adolescentes em capitais brasileiras: os conselhos de direitos importam?", in L. Avritzer (org.), A dinâmica da participação local no Brasil, São Paulo, Cortez.

MINAS GERAIS. (2016a), Lei no 21.972, de 21 de janeiro 2016. Dispóe sobre o Sistema Estadual de Meio Ambiente e Recursos Hídricos - Sisema - e dá outras providências.

MINAS GERAIS. (2016b), Decreto no 46.937, de 21 de janeiro de 2016. Regulamenta o art. 28 da Lei no 21.972, de 21 de janeiro de 2016, e dá outras providências.

MINAS GERAIS. (2017), Deliberação Normativa 213/2017, do Conselho Estadual de Política Ambiental. Regulamenta o disposto no art. 9o, inciso XIV, alínea “a” e no art. $18, \$ 2^{\circ}$ da Lei Complementar Federal no 140 , de 8 de dezembro de 2011, para estabelecer as tipologias de empreendimentos e atividades cujo licenciamento ambiental será atribuição dos Municípios.

PIRES, Roberto Rocha C. (2011), Efetividade das instituiçôes participativas no Brasil: estratégias de avaliação, Brasília, IPEA.

PIRES, Roberto Rocha C. \& VAZ, Alexander Cambraia N. (2010), "Participação faz diferença? Uma avaliação das características e efeitos da institucionalização da participação nos municípios brasileiros", in L. Avritzer (org.), A dinâmica da participação local no Brasil, São Paulo, Cortez.

RODRIGUES, Fernando Peres. (2017). A efetividade dos conselhos municipais de habitação: mecanismos entre decisão e implementação. Dissertação de mestrado. Faculdade de Filosofia, Letras e Ciências Humanas da Universidade de São Paulo, São Paulo.

SOUZA, Donaldo Bello de \& VASCONCELOS, Maria Celi Chaves. (2006), "Os conselhos municipais de educação no Brasil: um balanço das referências nacionais (1996-2002)”. Ensaio: Avaliação e Políticas Públicas em Educação, 14 (50): 39-56. doi.org/10.1590/S0104-40362006000100004.

TATAGIBA, Luciana. (2004), "A institucionalização da participação: os conselhos municipais de políticas públicas na cidade de São Paulo”, in L. Avritzer (org.), A participação em São Paulo, São Paulo, Unesp.

TATAGIBA, Luciana. (2007a), "O papel do CMDCA na política de atendimento à criança e ao adolescente em São Paulo”, in A. Santos \& L. Tatagiba (org.), 
Criança e adolescente: controle social e política pública, São Paulo, Instituto Pólis/ PUC-SP

TATAGIBA, Luciana. (2007b), "O papel do COMAS na política de assistência social em São Paulo", in C. C. Arregui; D. N. Blanes; M. B. Wanderley; R. Reichalis; R. D. O. Paz; V. A. Santos; L. Tatagiba, Assistência social: controle social e política pública, São Paulo, Instituto Pólis/ PUC-SP.
TEIXEIRA, Lucia Helena G. (2004), "Conselhos municipais de educação: autonomia e democratizaçáo do ensino". Cadernos de Pesquisa, 34, 123: 691-708. doi.org/10.1590/S0100-15742004000300009.

VELLO, Bruno Grisotto. (2018), Inovação democrática e desconfiança: o controle das políticas públicas nos conselhos. Dissertação de mestrado. Faculdade de Filosofia, Letras e Ciências Humanas da Universidade de São Paulo, São Paulo. 


\section{CONSELHOS E REGIMES DE NORMATIZAÇÁO - PADRÓES DECISÓRIOS EM MUNICÍPIOS DE GRANDE PORTE}

\author{
Adrian Gurza Lavalle, Hellen \\ Guicheney, Bruno Grisotto Vello
}

Palavras-chave: conselhos, políticas públicas, regimes de normatizaçáo, tipologia, especificação institucional, indução federal.

$\mathrm{O}$ artigo argumenta que regimes de normatizaçáo subnacional de caráter estadual podem modificar, consideravelmente, a atuação dos conselhos gestores de políticas no plano municipal. $\mathrm{O}$ argumento tem implicaçóes relevantes, porque o conhecimento acumulado sobre os conselhos descansa na premissa da prevalência de regimes nacionais de normatização, responsáveis por produzir convergência local na atuação dessas instituições, por setor de políticas. Apresentam-se resultados inéditos, comparando-se a produção decisória de 77 conselhos, mediante o exame de cerca de 15 mil resoluções, em cinco municípios de grande porte Fortaleza, Belo Horizonte, Porto Alegre, Goiânia e Guarulhos , escolhidos a partir de uma amostra intencional, segundo a disponibilidade de dados. Especificamente, com base em uma tipologia de conselhos que permite agregar as decisôes e projetar resultados esperados, examinam-se o volume e escopo das resoluçóes, bem como a dispersão desses dois atributos entre conselhos do mesmo setor. O padráo decisório encontrado confirma que a descrição standard dos conselhos, informada por uma narrativa focada no plano nacional, corresponde a parte significativa dos conselhos, mas lhe escapa uma parte deles com atividade decisória anômala, plausivelmente animada por regimes estaduais de normatização.

\section{REGULATORY COUNCILS AND REGIMES - DECISION STANDARDS IN LARGE MUNICIPALITIES}

\section{Adrian Gurza Lavalle, Hellen Guicheney, Bruno Grisotto Vello}

Keywords: councils, public policies, standardization regimes, typology, institutional specification, federal induction.

This article argues that subnational standardization regimes of a state character can considerably modify the performance of policy management councils at the municipal level. This argument has relevant implications, as accumulated knowledge concerning councils rests on the premise of the prevalence of national standardization regimes, responsible for producing local convergence in the performance of these institutions, per policy sector. Unpublished results are presented, comparing the decision-making of 77 councils, through the examination of about 15 thousand resolutions, in five large municipalities, namely Fortaleza, Belo Horizonte, Porto Alegre, Goiânia and Guarulhos, chosen from an intentional sample according to data availability. Specifically, the volume and scope of resolutions are examined based on a typology of councils that allows aggregating decisions and projecting expected results, as well as the dispersion of these two attributes among councils belonging to the same sector. The decision pattern found herein confirms that the standard description of the councils, informed by a narrative focused at the national level, corresponds to a significant portion of all councils, although some of them exhibit anomalous decision-making activity, plausibly enlivened by state normative regimes.

\section{CONSEILS ET RÉGIMES DE NORMALISATION - MODÈLES DÉCISIONNELS DANS LES MUNICIPALITÉS DE PLUS DE 100 000 HABITANTS}

\author{
Adrian Gurza Lavalle, Hellen \\ Guicheney, Bruno Grisotto Vello
}

Mots-clés: conseils, politiques publiques, régimes de normalisation, typologie, spécification institutionnelle, incitation du gouvernement fédéral.

L'article entend démontrer que des régimes de normalisation infranationale à caractère étatique peuvent modifier considérablement l'action des conseils chargés de la gestion municipale des politiques. Il part de l'idée selon laquelle les connaissances accumulées sur les conseils reposent sur la prémisse de la prévalence de régimes nationaux de normalisation, responsables d'une convergence locale au niveau de l'action de ces institutions, par secteur de politiques. Des résultats inédits ont été obtenus à partir de la comparaison des décisions de 77 conseils et de l'examen de près de 15 000 résolutions de cinq villes brésiliennes de plus de 100000 habitants: Fortaleza, Porto Alegre, Belo Horizonte, Goiânia et Guarulhos - des villes choisies sur la base d'un échantillonnage intentionnel, selon les données disponibles. Plus spécifiquement, le volume et la portée des résolutions, ainsi que la distribution de ces deux attributs parmi les conseils du même secteur, sont étudiés à partir d'une typologie de conseils permettant de rassembler les décisions et de projeter les résultats attendus. Le modèle décisionnel observé confirme que la description standard des conseils, étayée par un récit centré sur le plan national, correspond à une grande partie des conseils. Néanmoins, il montre qu'il existe aussi une activité de décision non standard, vraisemblablement menée par des régimes étatiques de normalisation. 
Anexo 1 - Lista de conselhos ativos (i.e., que publicaram decisóes nos DOs municipais entre 20052011), segundo tipologia de conselhos (C1, C2, C3)

$\mathrm{Na}$ fase da pesquisa apresentada neste texto, realizou-se levantamento exaustivo de todos os conselhos e suas decisões, entre 2005 e 2011, nos respectivos DOs locais. Foram identificadas 138 unidades, sendo que 77 publicaram resoluções - aqui, nomeadas "conselhos ativos". 30

\begin{tabular}{|c|c|c|c|c|c|c|c|}
\hline Tipo & Setor de Política & Belo Horizonte & Fortaleza & Goiânia & Guarulhos & Porto Alegre & $\mathbf{N}$ \\
\hline \multirow{3}{*}{$\mathrm{C} 1$} & Assistência Social & 1 & 1 & 1 & 1 & 1 & 5 \\
\hline & Criança e Adolescente & 1 & 1 & 1 & 1 & 1 & 5 \\
\hline & Saúde & 1 & 1 & 1 & 1 & 1 & 5 \\
\hline \multirow{11}{*}{$\mathrm{C} 2$} & Habitação & 1 & 1 & 1 & 1 & 1 & 5 \\
\hline & Educação & 1 & 0 & 1 & 1 & 1 & 4 \\
\hline & Idoso & 1 & 0 & 1 & 1 & 1 & 4 \\
\hline & Meio Ambiente & 1 & 1 & 1 & 0 & 1 & 4 \\
\hline & Patrimônio & 1 & 0 & 1 & 1 & 1 & 4 \\
\hline & Cultura & 0 & 1 & 0 & 1 & 1 & 3 \\
\hline & Alimentação Escolar & 1 & 0 & 0 & 1 & 0 & 2 \\
\hline & Drogas & 1 & 0 & 0 & 1 & 0 & 2 \\
\hline & Educação - Fundos & 1 & 0 & 0 & 1 & 0 & 2 \\
\hline & Trabalho/Emprego & 0 & 1 & 0 & 0 & 1 & 2 \\
\hline & Bolsa Família & 0 & 0 & 0 & 1 & 0 & 1 \\
\hline \multirow{17}{*}{$\mathrm{C} 3$} & Segurança Alimentar & 1 & 1 & 1 & 1 & 1 & 5 \\
\hline & Deficiência & 1 & 0 & 0 & 1 & 1 & 3 \\
\hline & Desenvolv. Urbano & 1 & 0 & 0 & 1 & 1 & 3 \\
\hline & Desenvolv. Econômico & 1 & 0 & 0 & 1 & 0 & 2 \\
\hline & Juventude & 1 & 0 & 0 & 1 & 0 & 2 \\
\hline & Raça & 1 & 0 & 0 & 1 & 0 & 2 \\
\hline & Defesa Do Consumidor & 0 & 1 & 0 & 0 & 1 & 2 \\
\hline & Mulher & 1 & 0 & 0 & 0 & 0 & 1 \\
\hline & Saneamento & 1 & 0 & 0 & 0 & 0 & 1 \\
\hline & Orçamento Participativo & 0 & 0 & 0 & 1 & 0 & 1 \\
\hline & Transporte & 0 & 0 & 0 & 1 & 0 & 1 \\
\hline & Turismo & 0 & 0 & 0 & 1 & 0 & 1 \\
\hline & Agricultura & 0 & 0 & 0 & 0 & 1 & 1 \\
\hline & Ciência e Tecnologia & 0 & 0 & 0 & 0 & 1 & 1 \\
\hline & Direitos Humanos & 0 & 0 & 0 & 0 & 1 & 1 \\
\hline & Esporte & 0 & 0 & 0 & 0 & 1 & 1 \\
\hline & Segurança & 0 & 0 & 0 & 0 & 1 & 1 \\
\hline Total & & 19 & 9 & 9 & 21 & 19 & 77 \\
\hline
\end{tabular}

Fonte: elaboraçáo própria. Projeto Conselhos, Regimes Subnacionais e Capacidades Estaduais. Centro de Estudos da Metrópole (CEM) 
Anexo 2 - Tipologia de atos administrativos emitidos pelos conselhos (ou tipologia de decisóes)

A tipificação das decisões demandou classificação, checagem e reclassificação por sucessivas rodadas de verificação cruzada (e cega). A tipologia resultante desse processo ordena as resoluções dos conselhos em cinco tipos:

\begin{tabular}{|c|c|c|}
\hline Tipo de decisáo & Descriçáo & Exemplos \\
\hline \multirow{5}{*}{$\begin{array}{l}\text { Definiçáo geral da } \\
\text { política e gestáo } \\
\text { orçamentárias (DEF) }\end{array}$} & \multirow{5}{*}{$\begin{array}{l}\text { Atos que definem a política, mediante o } \\
\text { estabelecimento de diretrizes, regulaçáes ou } \\
\text { definiçáo de critérios com caráter geral e de } \\
\text { natureza vinculante. Inclui, ainda, a aprovação, } \\
\text { ou não, de metas e peças orçamentárias da } \\
\text { política. São atos de natureza ex ante, que } \\
\text { incidem sobre a política antes de sua realização. }\end{array}$} & $\begin{array}{l}\text { - Aprovaçáo ou denegaçáo de orçamentos e } \\
\text { planos municipais; }\end{array}$ \\
\hline & & $\begin{array}{l}\text { - Aprovação ou denegação de projetos } \\
\text { do Executivo e da adesáo a programas } \\
\text { supramunicipais; }\end{array}$ \\
\hline & & $\begin{array}{l}\text { - Definiçáo de critérios para prestação de } \\
\text { contas; }\end{array}$ \\
\hline & & $\begin{array}{l}\text { - Definição de critérios para convênios } \\
\text { projetos e inscriçốes de Organizaçôes da } \\
\text { Sociedade Civil; }\end{array}$ \\
\hline & & $\begin{array}{l}\text { - Regulação ambiental e urbana, e } \\
\text { demarcaçóes públicas, por meio de } \\
\text { tombamentos e definiçóes do zoneamento } \\
\text { da cidade. }\end{array}$ \\
\hline \multirow{4}{*}{$\begin{array}{l}\text { Fiscalizaçáo da política } \\
\text { e atos de transparência } \\
\text { do conselho (FISC) }\end{array}$} & \multirow{4}{*}{$\begin{array}{l}\text { Atos em que o conselho age como fiscalizador, } \\
\text { em lógica próxima ao conceito de accountability. } \\
\text { Ao analisar, aprovar ou reprovar prestaçóes de } \\
\text { contas da execuçáo da política e de seus projetos } \\
\text { específicos, o conselho pode responsabilizar e, até } \\
\text { mesmo, aplicar sançóes aos atores que controla. } \\
\text { Trata-se de decisóes ex post, que incidem sobre a } \\
\text { política, após sua implementação. Inclui, ainda, } \\
\text { atos de transparência, em que o próprio conselho } \\
\text { é accountable a outros atores. }\end{array}$} & $\begin{array}{l}\text { - Aprovação ou denegaçáo de prestaçáo de } \\
\text { contas de fundos setoriais utilizados pelo } \\
\text { Executivo; }\end{array}$ \\
\hline & & $\begin{array}{l}\text { Aprovação ou denegaçáo de relatórios de } \\
\text { cumprimento de projetos do Executivo e de } \\
\text { Organizaçóes da Sociedade Civil; }\end{array}$ \\
\hline & & $\begin{array}{l}\text { - Puniçáo a OSCs, pela utilizaçáo irregular } \\
\text { de recursos de fundos setoriais; }\end{array}$ \\
\hline & & $\begin{array}{l}\text { - Julgamento de recursos interpostos por } \\
\text { atores que sofreram sançóes, devido a } \\
\text { irregularidades ambientais. }\end{array}$ \\
\hline \multirow{4}{*}{$\begin{array}{l}\text { Gestáo administrativa } \\
\text { da política (GEST) }\end{array}$} & \multirow{4}{*}{$\begin{array}{l}\text { Atos de natureza administrativa (gestão), que } \\
\text { dizem respeito à implementação da política, } \\
\text { uma vez que essa já foi definida e, sua execução, } \\
\text { regulada (em atos anteriores de definição). } \\
\text { Inclui, ainda, atos imediatamente anteriores à } \\
\text { implementação da política (ex ante), mas que } \\
\text { não definem nem regulam a política ou critérios } \\
\text { de sua execução, tratando apenas de orientaçôes } \\
\text { específicas para sua implementaçáa. }\end{array}$} & $\begin{array}{l}\text { - Aprovação ou denegaçáo de obras e } \\
\text { aquisiçóes de produtos e serviços pelo } \\
\text { Executivo; }\end{array}$ \\
\hline & & $\begin{array}{l}\text { - Aprovação ou denegação de destinaçáo de } \\
\text { saldos remanescentes de fundos públicos; }\end{array}$ \\
\hline & & $\begin{array}{l}\text { - Aprovaçáo ou denegaçáo de planos de } \\
\text { aplicaçáo de recursos, projetos de execuçáo } \\
\text { e planos de trabalho de projetos aprovados } \\
\text { anteriormente; }\end{array}$ \\
\hline & & $\begin{array}{l}\text { - Gestão da inscrição e de parcerias e } \\
\text { convênios com organizaçóes da sociedade } \\
\text { civil, para a implementação das políticas. }\end{array}$ \\
\hline \multirow{5}{*}{$\begin{array}{l}\text { Autorregulaçáo e } \\
\text { autogestáo (AUTO) }\end{array}$} & \multirow{5}{*}{$\begin{array}{l}\text { Atos a respeito do funcionamento interno do } \\
\text { conselho e da conduta de seus conselheiros. } \\
\text { Trata-se da publicação de decisóes que recaem } \\
\text { sobre o próprio conselho. Por isso, remetem mais } \\
\text { às disputas sobre o papel do conselho e do perfil } \\
\text { dos atores facultados a pleitear e ocupar cadeiras, } \\
\text { do que à incidência sobre a respectiva política } \\
\text { setorial. }\end{array}$} & $\begin{array}{l}\text { - Definição do calendário de } \\
\text { funcionamento; }\end{array}$ \\
\hline & & $\begin{array}{l}\text { - Criaçáo de instâncias internas de divisão } \\
\text { do trabalho; }\end{array}$ \\
\hline & & - Regulamentação e supervisão das eleiçôes; \\
\hline & & - Constituição dos colegiados internos; \\
\hline & & $\begin{array}{l}\text { - Definição e alteraçôes do regimento } \\
\text { interno. }\end{array}$ \\
\hline
\end{tabular}

Fonte: elaboração própria. Projeto Conselhos, Regimes Subnacionais e Capacidades Estaduais. Centro de Estudos da Metrópole 
Anexo 2 - Continuação...

$\begin{array}{lll}\text { Tipo de decisáo } & \text { Descriçáo } & \text { Exemplos }\end{array}$

- Aprovação ou denegaçáo de regimento interno das instâncias;

- Convocaçáo de eventos, como

Atos remetidos a instâncias setoriais de inovação conferências;

Gestáo e regulaçáo de democrática sob autoridade do conselho. Inclui

- Homologação de decisóes tomadas outras instâncias que decisóes sobre critérios para a organização e o previamente por instâncias;

envolvem participaçáo funcionamento dessas instâncias, bem como atos (IP) referentes à gestáo de suas atividades regulares e das eleições de seus membros.

- Criação de grupos de trabalho em outras instâncias;

- Aprovação de repasses de recursos para a viabilização de conferências;

- Organização das eleiçóes e processos de composição das instâncias.

Fonte: elaboração própria. Projeto Conselhos, Regimes Subnacionais e Capacidades Estaduais. Centro de Estudos da Metrópole 